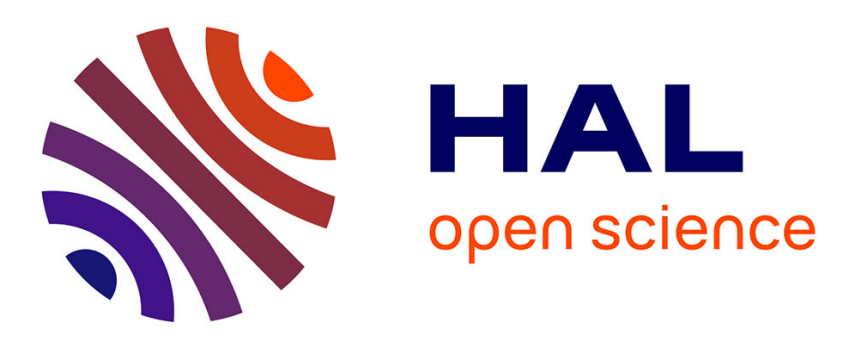

\title{
Multitemporal Relationships Between the Hydroclimate and Exports of Carbon, Nitrogen, and Phosphorus in a Small Agricultural Watershed
}

L. Strohmenger, Ophélie Fovet, Nouraya Akkal-Corfini, M. Faucheux, Rémi Dupas, Patrick Durand, Gérard Gruau, Y. Hamon, Anne Jaffrézic, C.

Minaudo, et al.

\section{To cite this version:}

L. Strohmenger, Ophélie Fovet, Nouraya Akkal-Corfini, M. Faucheux, Rémi Dupas, et al.. Multitemporal Relationships Between the Hydroclimate and Exports of Carbon, Nitrogen, and Phosphorus in a Small Agricultural Watershed. Water Resources Research, 2020, 56 (7), pp.e2019WR026323. 10.1029/2019WR026323 . insu-02917885

\section{HAL Id: insu-02917885 \\ https://hal-insu.archives-ouvertes.fr/insu-02917885}

Submitted on 20 Aug 2020

HAL is a multi-disciplinary open access archive for the deposit and dissemination of scientific research documents, whether they are published or not. The documents may come from teaching and research institutions in France or abroad, or from public or private research centers.
L'archive ouverte pluridisciplinaire HAL, est destinée au dépôt et à la diffusion de documents scientifiques de niveau recherche, publiés ou non, émanant des établissements d'enseignement et de recherche français ou étrangers, des laboratoires publics ou privés. 


\section{Water Resources Research}

\section{RESEARCH ARTICLE 10.1029/2019WR026323 \\ Special Section: \\ Dynamics in Intensively \\ Multitemporal Relationships Between the Hydroclimate and Exports of Carbon, Nitrogen, and Phosphorus in a Small Agricultural Watershed} Managed Landscapes: Water, Sediment, Nutrient, Carbon, and Ecohydrology

Key Points:

- We analysed 16 years of daily hydroclimatic and water chemistry variables in a $5 \mathrm{~km}^{2}$ agricultural watershed

- Opposite temporal patterns were observed for nitrate and DOC, independent of SRP variations, at interannual, seasonal, and event time scales

- Agricultural pressures and climate drive long-term trends, while watershed wetness controls shorter-term variations

Supporting Information:

- Supporting Information S1

Correspondence to:

L. Strohmenger and O. Fovet, laurent.strohmenger@inrae.fr; ophelie.fovet@inrae.fr

Citation:

Strohmenger, L., Fovet, O. Akkal-Corfini, N., Dupas, R., Durand, P., Faucheux, M., et al. (2020). Multitemporal relationships between the hydroclimate and exports of carbon, nitrogen, and phosphorus in a small agricultural watershed. Water Resources Research, 56, e2019WR026323. https://doi.org/ 10.1029/2019WR026323

Received 12 SEP 2019

Accepted 18 MAY 2020

Accepted article online 26 MAY 2020

2020. American Geophysical Union. All Rights Reserved.

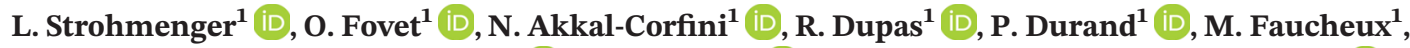 \\ G. Gruau' ${ }^{2}$ Y. Hamon ${ }^{1}$ A. Jaffrezic ${ }^{1}$ (D) C. Minaudo ${ }^{3}$ iD, P. Petitjean ${ }^{2}$, and C. Gascuel-Odoux ${ }^{1}$ \\ ${ }^{1}$ UMR SAS, INRAE, AGROCAMPUS OUEST, Rennes, France, ${ }^{2}$ OSUR, Géosciences Rennes, CNRS, Rennes, France, \\ ${ }^{3}$ Physics of Aquatic Systems Laboratory, EPFL, Lausanne, Switzerland
}

\begin{abstract}
Agriculture affects the biogeochemical cycles of carbon, nitrogen, and phosphorus, leading to a deterioration of surface water quality. The increasing magnitude of climate change raises questions about potential additional or mitigating effects of climate change on this deterioration. One way to understand these potential effects is to cross-analyze the dynamics of nutrient concentrations and hydroclimatic variables at multiple time scales. Here, we used a 16-year data set, from a $5 \mathrm{~km}^{2}$ agricultural watershed in France with a temperate oceanic climate, that contains a daily record of nutrient concentrations and hydroclimatic variables from 2002-2017. We calculated Mann-Kendall and Theil-Sen tests, Fourier transforms, and daily hydroclimatic distributions associated with extreme stream concentrations to investigate long-term trends, seasonal dynamics and their interannual variations, and the daily time scale, respectively. Dynamics of dissolved organic carbon (DOC) and nitrate $\left(\mathrm{NO}_{3}\right)$ concentrations displayed opposite patterns at the three temporal scales, while soluble reactive phosphorus concentrations showed decoupled dynamics, related more to extreme hydrological events. Climate and past agricultural changes seem to have a synergetic effect that leads to long-term $\mathrm{NO}_{3}$ decrease and DOC increase. Precipitation and, to a greater extent, watershed wetness controlled seasonal and event-driven dynamics.
\end{abstract}

\section{Introduction}

Assessing water quality and its evolution is a major issue for society in the context of global change (Nickus et al., 2010). Effects of climate on water quality have often been studied for large rivers, since rivers concentrate most long-term water quality time series. However, it is difficult to disentangle hydrological and biogeochemical effects in the terrestrial and aquatic compartments of watersheds from observations in large rivers (Marzadri et al., 2017). Studies of small rivers or streams are more likely to reveal effects of climate change on nutrient mobilization dynamics in watersheds, but these studies remain relatively rare (Ford et al., 2018). These dynamics result from complex interactions between the watershed structure (e.g., geology, topography, and soils) and anthropogenic and hydroclimatic drivers (Basu et al., 2010; Davis et al., 2014; Dick et al., 2015). Climate influences surface water chemistry via both hydrological and biogeochemical mechanisms (Bartolai et al., 2015; Delpla et al., 2009; Green et al., 2014; Marshall \& Randhir, 2008; Ockenden et al., 2017; Stuart et al., 2011). Indeed, climate drives the hydrological budget and flow paths and thus mobilization of chemical elements and their residence times. In addition, climate also influences biogeochemical reactions that depend on temperature and wetness (Covino, 2017; Salmon-Monviola et al., 2013; Stuart et al., 2011; Whitehead et al., 2009). The response of water quality to climate change is thus likely to differ among chemical elements depending on their sources and mobilization pathways and on their sensitivity to climate versus local anthropogenic drivers. Therefore, integrated approaches that study multiple elements are required to understand and predict the future of water quality in agricultural areas. For instance, dissolved organic carbon (DOC) is assumed to be more sensitive to temperature (Delpla et al., 2009; Singh et al., 2016) but less sensitive to agriculture than nitrates $\left(\mathrm{NO}_{3}\right)$ or soluble reactive $\mathrm{P}$ (SRP) (Bennett et al., 2001; Galloway \& Cowling, 2002). $\mathrm{NO}_{3}$ and SRP also have different sources and mobilization processes (Basu et al., 2011; Bowes et al., 2015; Thomas et al., 2016).

The reported effects of climate on $\mathrm{C}, \mathrm{N}$, and $\mathrm{P}$ concentrations depend on the element and the temporal scale: 
1. Over periods longer than a decade, considered here to be "long-term," available water-quality time series cover mainly North of America and Europe. Several trends in these time series have been observed. Increases in DOC concentration (Monteith et al., 2007; Worrall \& Burt, 2007) are usually attributed to climate warming and global (pH, deposition) changes. Decreases in $\mathrm{NO}_{3}$ (Aquilina et al., 2012; Dupas, Minaudo, et al., 2018; Howden et al., 2010; Monteith et al., 2000) and SRP (Bowes et al., 2011; Dupas, Tittel, et al., 2018; Minaudo et al., 2015) concentrations are attributed to changes in agricultural and household pressures or hydroclimatic changes.

2. Over shorter periods (a few years), climate cycles occur in a succession of wet and cold years followed by dry and warm years, related to the North Atlantic Oscillation in Northern Europe. Several studies have identified responses of stream concentrations of $\mathrm{NO}_{3}$ and SRP to these cycles (Gascuel-Odoux et al., 2010; Loecke et al., 2017; Mellander et al., 2018; Monteith et al., 2000).

3. At the annual scale, seasonal variations in weather induce strong seasonality in hydrology and biogeochemistry, leading to seasonal variations in stream concentrations (Abbott et al., 2018; Aubert et al., 2013; Halliday et al., 2012; Martin et al., 2004; Mulholland \& Hill, 1997). For headwaters controlled by a shallow water table, water table fluctuation is the main driver of dissolved C, N, and P seasonality (Musolff et al., 2015; Newcomer et al., 2018; Van Meter et al., 2019). Indeed, it controls the connectivity between solute sources (e.g., in soils or groundwater) and the stream, as well as soil moisture, which influences biogeochemical processes such as reduction and mineralization.

4. Finally, the precipitation regime is the main driver of the storm regime, which is responsible for most export of DOC (Lambert et al., 2013; Morel et al., 2009) and SRP (Bowes et al., 2015; Dupas, Tavenard, et al., 2015; Outram et al., 2014), while stormflow usually dilutes $\mathrm{NO}_{3}$ concentrations (Bowes et al., 2015; Oeurng et al., 2010).

Few studies have investigated water quality response to local climatic conditions considering (i) multiple elements (Michalak, 2016; Singh et al., 2016; Whitehead et al., 2009) with contrasting sources, mobilization, and reactivity, such as $\mathrm{DOC}, \mathrm{NO}_{3}$, and SRP, and (ii) several temporal scales (from 1 day to decades). Such studies require high-frequency multielement sampling in small-scale watersheds over a long period ( $>10$ years). We developed an approach to perform such an analysis to address the following questions:

1. Are there measurable changes in climatic, hydrological, and concentration variables?

2. How do changes in annual weather/water regimes influence seasonal variations in concentrations?

3. How do changes in extreme conditions, such as storm events and droughts, influence stream concentrations?

We analyzed the covariability of climatic variables and $\mathrm{DOC}, \mathrm{NO}_{3}$, and SRP stream water concentrations by comparing (1) their long-term trends over a 16-year period, (2) the synchrony of average and interannual seasonal patterns, and (3) daily hydroclimatic conditions associated with low and high concentrations for different hydrological regimes, using a suitable method for each temporal scale. We used an original daily data set for 2002-2017 from an Environmental Research Observatory (ERO) containing daily meteorological and hydrological variables, as well as $\mathrm{DOC}, \mathrm{NO}_{3}$, and SRP stream water concentrations. This data set was well suited to conduct an analysis that addressed the criteria of length ( $>10$ years), frequency $(<1$ week), and multiple elements (C, N, and P).

\section{Methods}

\subsection{Study Site}

The Kervidy-Naizin study site is a $4.9-\mathrm{km}^{2}$ agricultural headwater located in western France that has been instrumented since the 1970s for long-term observations (Figure 1). This research watershed belongs to the ERO AgrHyS (ERO of response times in Agro-Hydro-Systems, https://www6.inra.fr/ore_agrhys_eng/; Fovet, Ruiz, et al., 2018; Gascuel-Odoux et al., 2018). It is one of the French Critical Zone Observatories (OZCAR) (Gaillardet et al., 2018).

The draining headwater stream is the Coët Dan, a second Strahler-order intermittent stream with high discharge periods from November-April and completely dry periods (no flow) from July-October. The mean \pm standard deviation of annual runoff was $296 \pm 150 \mathrm{~mm}$ for 2002-2017. The climate is temperate oceanic, with mean annual temperature of $11.2 \pm 0.6^{\circ} \mathrm{C}$ and mean annual precipitation of $810 \pm 180 \mathrm{~mm}$. 


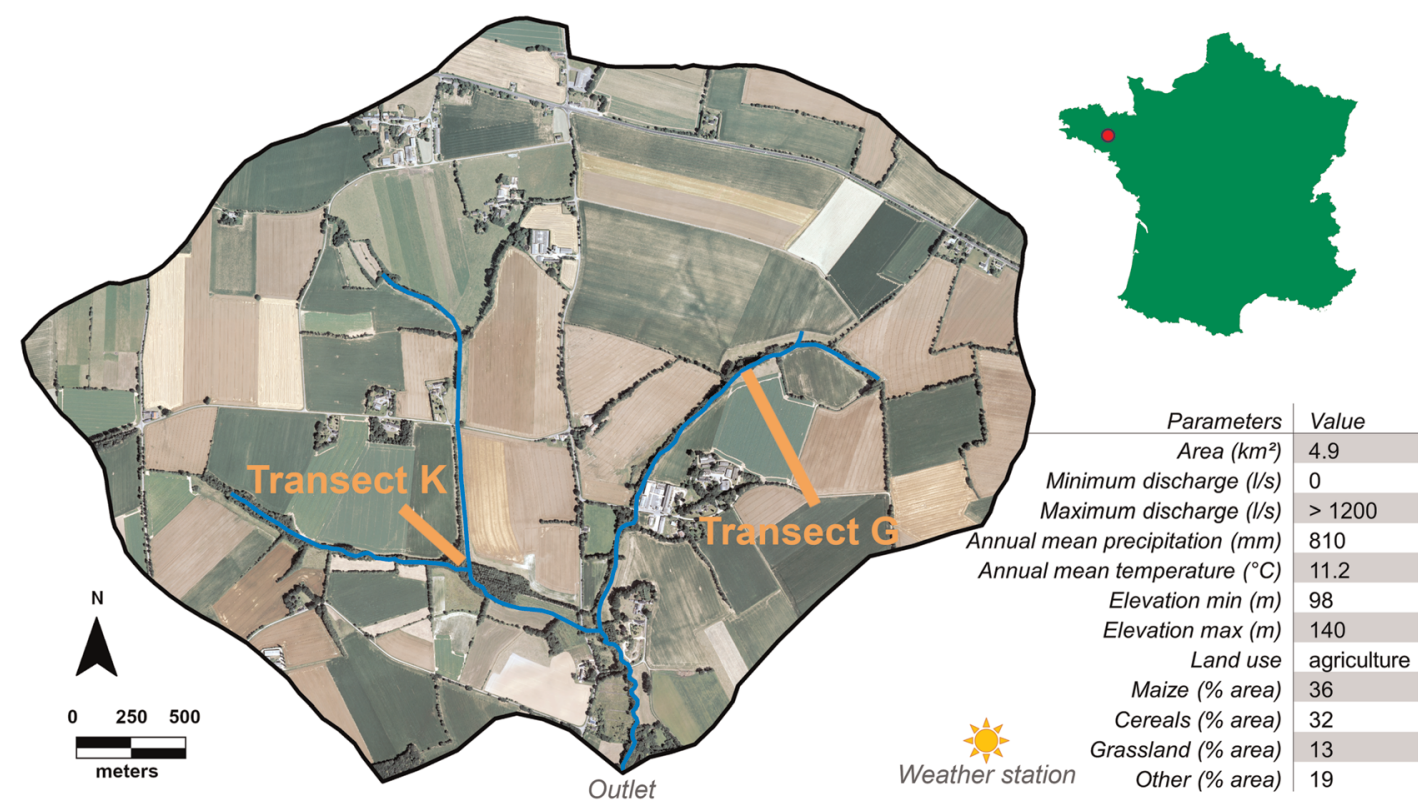

Figure 1. Aerial photograph of the Kervidy-Naizin watershed, showing the locations of the stream and transects $\mathrm{K}$ and $\mathrm{G}$.

Precipitation varies seasonally throughout the year, with higher precipitation from October-February (mean monthly precipitation of $92 \pm 31 \mathrm{~mm}$ ) and lower precipitation from March-July (mean monthly precipitation of $50 \pm 14 \mathrm{~mm}$ ).

The Kervidy-Naizin watershed is mostly flat with a maximum slope $<5 \%$ and elevation that ranges from 98-140 m above sea level. The bedrock is composed of impermeable Brioverian schists with pyrite $\left(\mathrm{FeS}_{2}\right)$, above which a locally fractured layer of schists is buried under 1-30 m of weathered material and silty loam soils.

Land use is characterized by intensive mixed farming, with $91 \%$ of the watershed area under agriculture that grows crops used for animal feed, primarily maize (silage or grain) and grasslands. The main crop rotations are maize-winter wheat or barley and maize-grasslands, which leads to a watershed area dominated by maize (36\%), cereals (32\%), and grasslands (13\%) according to farm surveys performed in 2008 and 2013 and to annual land-use surveys (Casal et al., 2019; Viaud et al., 2018). The watershed has a high livestock density ( 5 livestock units per hectare), composed of cattle, pigs, and poultry (Casal et al., 2019).

Agricultural production intensified during the 1970s, leading to an increase in mineral N, P, and livestock organic matter (OM) inputs (Cheverry, 1998). Following environmental policies in the 1990s (European Union Nitrates Directive and national implementations), agricultural practices changed to reduce nutrient inputs, which decreased the most from 1998-2008. From 1993-2000, the first Management Plan for Agricultural Pollution (the French "Plan de Maitrise des Pollutions d'Origine Agricole") targeted the standardization of livestock buildings and improvement of manure storage. The Second Management Plan (2001-2008) imposed fertilization management plans, optimization of grazing strategies, mandatory soil coverage, and manure processing. From 2008-2017, agricultural management and land use likely continued to evolve but to a lesser extent. Local farm surveys performed before 1995 led to estimates of annual soil N surplus (mineral + organic inputs - crop exportations) of $\sim 150-200 \mathrm{~kg} \mathrm{~N} \cdot \mathrm{ha}^{-1} \cdot \mathrm{y}^{-1}$ (Cheverry, 1998). Farm surveys performed in 2008 and 2013 led to estimates of the average annual surplus over the studied period (2002-2017) of $100 \mathrm{~kg} \mathrm{~N} \cdot \mathrm{ha}^{-1} \cdot \mathrm{y}^{-1}$ (Casal et al., 2019) and $13 \mathrm{~kg} \mathrm{P} \cdot \mathrm{ha}^{-1} \cdot \mathrm{y}^{-1}$ (Dupas, Gruau, et al., 2015).

Previous studies highlighted a strong annual pattern in the dynamics of hydrological and chemical elements in the Kervidy-Naizin watershed (Aubert et al., 2013). Analysis of seasonal and annual means and variances emphasized a sequence of four hydrological periods during the water year associated with different flow paths and shallow groundwater fluctuations: (1) rising of base flow, (2) high base flow, (3) recession of base flow, and (4) dry (Dupas, Gascuel-Odoux, et al., 2015; Humbert et al., 2015). Tracer experiments and 
multicompartment monitoring for 1-2 years each indicated that this sequence controlled biogeochemical processes (Aubert et al., 2013; Dupas, Gascuel-Odoux, et al., 2015; Fovet, Humbert, et al., 2018; Humbert et al., 2015; Lambert et al., 2013), mobilization of biogeochemical elements (Lambert et al., 2013), and transport mechanisms during storm events (Aubert et al., 2013; Dupas, Gascuel-Odoux, et al., 2015; Fovet, Humbert, et al., 2018). DOC and SRP exports were found to be controlled by the hydrological connectivity of wetland soils with the stream (Dupas, Gascuel-Odoux, et al., 2015; Humbert et al., 2015), while $\mathrm{NO}_{3}$ export was related to contribution from the groundwater reservoir during high base flow and recession periods (Molenat et al., 2002). No synthetic study has yet been performed to analyze and compare concentrations of $\mathrm{C}, \mathrm{N}$, and $\mathrm{P}$, and their synchrony or asynchrony with climate drivers, using the same method for a given temporal scale. In addition, the longer data set used in the present study allows for assessment of whether the previous findings are consistent over the years and analysis of trends.

\subsection{Solute Monitoring}

Stream water was sampled manually every day at 17:00 at the outlet station. Samples were filtered in the field (pore size: $0.22 \mu \mathrm{m}$ for $\mathrm{C}$ and anions and $0.45 \mu \mathrm{m}$ for $\mathrm{P}$ analyses) and stored in the dark at $4^{\circ} \mathrm{C}$ in propylene bottles. Analyses were performed within 2 weeks of sampling. $\mathrm{NO}_{3}$, chloride $(\mathrm{Cl})$, and sulfate $\left(\mathrm{SO}_{4}\right)$ concentrations were measured by ionic chromatography (DIONEX DX 100, ISO 10304, 1995; precision: 2.5\%). Quantification and detection limits were respectively 0.23 and $0.77 \mathrm{mg} \cdot \mathrm{l}^{-1}$ for $\mathrm{Cl}, 0.54$ and 1.79 for $\mathrm{NO}_{3}$, and 0.42 and 1.40 for $\mathrm{SO}_{4}$. Total and dissolved inorganic carbon (TDC and DIC) concentrations were measured using a carbon analyzer (Shimadzu TOC 5050A, Petitjean et al. (2004), precision: $0.5 \mathrm{mg} \cdot 1^{-1}$ ). DOC was estimated as TDC minus DIC (precision: $0.7 \mathrm{mg} \cdot \mathrm{l}^{-1}$ ). Quantification and detection limits were respectively 0.31 and $0.41 \mathrm{mg} \cdot 1^{-1}$ for DIC and 0.23 and 0.31 for DOC. SRP concentration was measured by colorimetric analysis after reaction with ammonium molybdate (ISO 15681, 2005; Murphy \& Riley, 1962; precision: $5 \%$, quantification and detection limits: 0.045 and $0.035 \mathrm{mg} \cdot \mathrm{l}^{-1}$, respectively). SRP concentrations were determined every 3 days from 2007-2015 and daily thereafter; thus, the corresponding time series are shorter. This study focused on $\mathrm{DOC}, \mathrm{NO}_{3}$, and $\mathrm{SRP}$ dynamics. $\mathrm{SO}_{4}$ and $\mathrm{Cl}$ were also included because of their common source with $\mathrm{DOC}$ and $\mathrm{NO}_{3}$, respectively, and thus their contribution to interpretation of $\mathrm{C}, \mathrm{N}$, and $\mathrm{P}$ variations. The laboratories are engaged in proficiency testing programs of BIPEA (https://www.bipea.org/).

\subsection{Hydroclimate}

We used daily records of meteorological, hydrological, and chemical variables monitored in the Kervidy-Naizin watershed from October 2001 to September 2017. The daily meteorological data were obtained from a weather station (Cimel Enerco 516i), located $1 \mathrm{~km}$ east of the outlet, that recorded precipitation (rain rate, RR), air temperature (AirTemp), global radiation (GR), and wind speed (Wind) each hour. Potential evapotranspiration (PET) was calculated using the Penman equation (Penman, 1956).

Water table level was measured every $15 \mathrm{~min}$ in 10 piezometers along two transects, G and K (Figure 1), by Orpheus OTT pressure probes. Stream level was recorded at the outlet every minute by a float-operated shaft-encoder level sensor (Thalimedes OTT), then converted to stream flow using a rating curve (Carluer, 1998) (Supporting Information S1). We calculated a daily mean level from these records.

To characterize watershed wetness, we calculated the Antecedent Precipitation Index (API) (Osborn \& Lane, 1969), which is calculated for each day $t$ based on the precipitation during previous days (equation 1).

$$
A P I(t)=\sum_{i=0}^{t} R R(t-i) \cdot \exp ^{-i k}
$$

where $k$ is the decreasing rate of the previous day's contribution (contributions $<5 \%$ were ignored).

We tested a wide range for values for $k$ and set it so that API integrated the precipitation of eight previous days, which had the highest correlation with $\mathrm{DOC}$ and $\mathrm{NO}_{3}$ concentrations. These variables are described in Supporting Information S2.

\subsection{Trend Detection}

The 16-year trends (hereafter, "long-term trends") were estimated for each variable and then compared to identify coevolutions. We used Mann-Kendall and Theil-Sen (TS) tests to identify trends and to quantify their magnitudes, respectively (He et al., 2015; Lloyd et al., 2014; Srinivas et al., 2020; Ye \& Kameyama, 2020). 
The Mann-Kendall score reflects the probability of a trend in the data set, while the TS slope (unit·year ${ }^{-1}$ ) is the median slope of a variable over the study period (2002-2017).

Unlike linear regression based on the least squares approach, the TS method is unaffected by potential outliers in the data. These tests were performed for all variables twice: within the complete time series and within different hydrological periods. These periods were divided slightly differently than those in previous studies of this watershed to ensure that a dry period and wet period were defined every year. The periods were defined using dry and wet thresholds set to the 10th and 75th percentiles, respectively, of the complete time series in flowing conditions. Because the dry period contained no-flow periods that lacked concentration data, trends were calculated from the three wettest periods only.

\subsection{Fourier Transform and Seasonal Signal Analysis}

At the seasonal scale, the objective was to describe each variable's average pattern throughout each year from 2002-2017, to assess the synchrony between water quality variables and hydroclimatic variables, and then compare the interannual variability in these seasonal patterns. We used a Fourier transform to analyze the seasonality in time series. Compared to previous analyses that aggregated data (by month or season) or used variograms (Aubert et al., 2013), Fourier transformation of these data sets allowed the magnitude and timing of dominant cyclic patterns in the data to be identified (Kędra et al., 2016). A discrete Fourier transform reproduces a signal with a combination of cosine and sine functions of several wavelengths (equation 2).

$$
\left\{\begin{array}{c}
F(t)=C+\sum_{n=1}^{12} A_{n} \cos \left(w_{n} t\right)+B_{n} \sin \left(w_{n} t\right) \\
w=\frac{2 \pi}{T}
\end{array}\right.
$$

where $F(t)$ is the Fourier series on day $t, C$ a constant offset, $n$ the harmonic number, $A_{n}$ and $B_{n}$ the amplitudes of cosine and sine, respectively, $w_{n}$ the pulsatance of the $n$th harmonic, and $T$ the longest wavelength.

We used 12 harmonics for this study: The longest harmonic wavelength was set to twice the length of the time series (32 years), and the next 11 harmonic wavelengths were set to half that of the previous harmonic (equation 3).

$$
w_{n}=2 \times w_{n-1}
$$

Harmonics of wavelength $>1$ year were considered to reproduce the interannual trend of the signal, while those with wavelength $\leq 1$ year were used to reproduce intra-annual variations. To assess the variability in this seasonal pattern among years, two characteristics were used for each variable: annual amplitude and the maximum-value phase. The Fourier series were fitted to minimize the sum of the residual between observed and calculated signals using the least-squares method, leading to calibrated amplitudes of the cosine and sine functions for each wavelength. Seasonality of the signals was assessed using two harmonics with pulsatance equal to 365 and 182.5 days. Amplitudes and phase shifts were calculated for each hydrological year individually. Year-to-year deviations from the average seasonal patterns were studied to identify, for instance, whether years with higher amplitudes of temperature were associated with higher amplitudes of concentrations, or whether early peaks of precipitation were associated with early peaks of concentration. A correlation matrix shows these potential correlations between amplitudes and phase shifts.

\subsection{Effect of Interannual Dry Periods}

The control of dry-period length on solute concentrations was investigated by comparing annual discharge-weighted concentration of the solutes to the length of the dry period. For each year, this period corresponded to a water table level in the downslope piezometer of transect $\mathrm{K}$ that was deeper than $30 \mathrm{~cm}$, and thus to the period when soil $\mathrm{C}$ and $\mathrm{P}$ wetland sources were disconnected from the stream (Humbert et al., 2015). 
Table 1

Long-Term Trends Calculated From 2002-2017 on the Kervidy-Naizin Watershed

\begin{tabular}{|c|c|c|c|c|c|c|c|}
\hline Trend & $\begin{array}{c}\text { DOC } \\
\left(\mathrm{mg} \mathrm{l}^{-1} \text { year }^{-1}\right)\end{array}$ & $\left(\mathrm{mg} \mathrm{l}^{-1}\right.$ year $\left.^{-1}\right)$ & $\begin{array}{c}\text { SRP } \\
\left(\mathrm{mg} \mathrm{l}^{-1} \text { year }^{-1}\right)\end{array}$ & $\left(\mathrm{mg} \mathrm{l}^{-1}\right.$ year $\left.^{-1}\right)$ & $\begin{array}{c}\mathrm{SO}_{4} \\
\left(\mathrm{mg} \mathrm{l}^{-1} \text { year }^{-1}\right)\end{array}$ & $\begin{array}{c}\mathrm{RR} \\
\left(\mathrm{mm}_{\text {year }}^{-1}\right)\end{array}$ & $\begin{array}{c}\mathrm{RR}+ \\
\left(\mathrm{mm}^{-} \text {year }^{-1}\right)\end{array}$ \\
\hline Overall & $3.4 \mathrm{E}-02$ & $-1.2 \mathrm{E}+00$ & $-1.3 E-03$ & $-4.4 E-01$ & $9.6 \mathrm{E}-02$ & $0.0 \mathrm{E}+00$ & $0.0 \mathrm{E}+00$ \\
\hline Recharge & $4.7 \mathrm{E}-02$ & $-1.2 \mathrm{E}+00$ & $-2.6 \mathrm{E}-03$ & $-2.3 \mathrm{E}-01$ & $4.2 \mathrm{E}-01$ & $0.0 \mathrm{E}+00$ & $0.0 \mathrm{E}+00$ \\
\hline Wet & $3.5 \mathrm{E}-02$ & $-1.5 \mathrm{E}+00$ & $-2.8 \mathrm{E}-05$ & $-5.2 \mathrm{E}-01$ & $6.2 \mathrm{E}-02$ & $0.0 \mathrm{E}+00$ & $0.0 \mathrm{E}+00$ \\
\hline Recession & $3.9 E-02$ & $-1.2 \mathrm{E}+00$ & $-1.1 \mathrm{E}-03$ & $-3.8 \mathrm{E}-01$ & $1.1 \mathrm{E}-01$ & $0.0 \mathrm{E}+00$ & $0.0 \mathrm{E}+00$ \\
\hline Trend & $\begin{array}{l}\text { PG1 } \\
\left(\mathrm{mm} \mathrm{year}^{-1}\right)\end{array}$ & $\begin{array}{l}\text { PG2 } \\
\left(\mathrm{mm}_{\text {year }}^{-1}\right)\end{array}$ & $\begin{array}{l}\text { PG3 } \\
\left(\mathrm{mm} \mathrm{year}^{-1}\right)\end{array}$ & $\begin{array}{l}\text { PG4 } \\
\left(\mathrm{mm}_{\text {year }}^{-1}\right)\end{array}$ & $\begin{array}{l}\text { PG5 } \\
\left(\mathrm{mm} \mathrm{year}^{-1}\right)\end{array}$ & $\begin{array}{l}\text { PG6 } \\
\left(\mathrm{mm} \mathrm{year}^{-1}\right)\end{array}$ & $\begin{array}{l}\text { PK1 } \\
\left(\mathrm{mm} \mathrm{year}^{-1}\right)\end{array}$ \\
\hline Overall & $9.2 \mathrm{E}-01$ & $-2.6 \mathrm{E}+00$ & $6.6 \mathrm{E}+00$ & $-6.5 \mathrm{E}+00$ & $-1.3 \mathrm{E}+01$ & $3.9 \mathrm{E}+00$ & $-7.0 \mathrm{E}+00$ \\
\hline Recharge & $1.5 \mathrm{E}+00$ & $-1.1 \mathrm{E}+01$ & $8.5 E+00$ & $2.4 \mathrm{E}+01$ & $-4.1 E+00$ & - & $-7.8 \mathrm{E}+00$ \\
\hline Wet & $1.0 \mathrm{E}+01$ & $8.7 \mathrm{E}+00$ & $1.2 \mathrm{E}+01$ & 2.1E+01 & $2.1 \mathrm{E}+01$ & $2.8 \mathrm{E}+01$ & $-1.9 E+00$ \\
\hline Recession & $-3.3 E+00$ & $-2.3 \mathrm{E}+00$ & $2.9 \mathrm{E}+00$ & $-2.3 \mathrm{E}+01$ & $-2.9 \mathrm{E}+01$ & $-2.8 \mathrm{E}+01$ & $-8.2 \mathrm{E}+00$ \\
\hline
\end{tabular}

Note. Overall trends are based on the complete time series. Hydrological periods' trends focus on three periods identified for hydrological activity of the watershed. Trend value is the annual Theil-Sen slope, which is in bold when Mann-Kendall test is significant $(p$ value $<0.05)$. Rain rate $>0(R R+)$, global radiation (GR), potential evapotranspiration (PET), bottomland piezometer (PG1, PK1), upland piezometer (PG6, PK4), daily discharge (Qd), and 8-day Antecedent Precipitation Index (API8).

\subsection{Analysis of Conditions Associated With the Highest and Lowest Concentrations}

For the complete time series, we compared the co-occurrence of the lowest and highest daily concentrations with those of the hydroclimatic variables. Base flow and stormflow conditions were analyzed separately. We split the data set into base flow and storm event conditions, based on differences in flow (Aubert et al., 2013). Storm events were identified when an increase in discharge exceeded $151 \cdot \mathrm{s}^{-1}$ for $10 \mathrm{~min}$. Then, discharge at peak flow was identified. The last value of discharge greater than the initial discharge determined the end of the storm event. Any day with a storm event, regardless of duration, was itself considered to be a storm event. Discharge intensity for each storm event was calculated as peak flow minus base flow, the latter being assumed to equal the initial discharge before the event.

To focus on co-occurrence of the highest and lowest concentrations, and to compare variables with different variances and non-normal distributions, we calculated a contingency table of the variables classified. First, we split each hydroclimatic variable into five quantiles (classes, Supporting Information S3). For RR, its many zero values (53\%) (days without precipitation) were allocated to Class 1 . Then, a subset of the rainy days (RR $>0 \mathrm{~mm}$ ) was subdivided into four classes based on its quartiles. Next, we calculated a $5 \times 5$ contingency table for each pair of $\mathrm{X}$ (concentration) and $\mathrm{Y}$ (hydroclimatic variable) variables. The $i$ th row and $j$ th column of the contingency table corresponded to the number of days when $\mathrm{X}$ was in Class $i$ and $\mathrm{Y}$ was in Class $j$. Then, the contingency table was converted into a table of relative frequency of occurrence by dividing each cell of row $i$ by the sum of days in that class Xi. Finally, these tables were plotted as a histogram for each concentration and each flow regime. Special focus was given to the distribution of classes X1 (lowest concentrations) and X5 (highest concentrations). Equal distribution of Xi among the classes of Y would suggest little relationship between $\mathrm{X} i$ and $\mathrm{Y}$. For a strong positive relationship between $\mathrm{X}$ and $\mathrm{Y}$, a high probability of association was expected between X1 and Y1 or between X5 and Y5, while for a strong negative relationship between $\mathrm{X}$ and $\mathrm{Y}$, a high probability of association was expected between $\mathrm{X} 1$ and $\mathrm{Y} 5$ or X5 and Y1.

All analyses were performed using MATLAB $^{\circledast}$ software (2019a).

\section{Results}

\subsection{Trends Over 16 Years}

Table 1 summarizes trends for each variable for the entire study period and for hydrological periods (recharge, wet, and recession), while Supporting Information S4 provides plots of time series and long-term trends. We focus the results and interpretation on the trends detected and their directions rather than their magnitude because of differences in units and the difficulty in normalizing trends of variables whose average was close to zero (e.g. water table levels in the downslope area frequently close to soil surface). 
Table 1

Continued

\begin{tabular}{|c|c|c|c|c|c|}
\hline Trend & $\left(\mathrm{j} \mathrm{cm}^{-2}\right.$ year $\left.^{-1}\right)$ & $\begin{array}{c}\text { Temp } \\
\left({ }^{\circ} \mathrm{C}_{\text {year }}{ }^{-1}\right)\end{array}$ & $\begin{array}{c}\text { Wind } \\
\left(\mathrm{m} \mathrm{s}^{-1} \text { year }^{-1}\right)\end{array}$ & $\begin{array}{c}\text { PET } \\
\left(\mathrm{mm} \mathrm{year}^{-1}\right)\end{array}$ & $\begin{array}{c}\text { RR-PET } \\
\left(\mathrm{mm} \mathrm{year}^{-1}\right)\end{array}$ \\
\hline Overall & $1.1 \mathrm{E}+00$ & $4.3 \mathrm{E}-02$ & $-2.1 \mathrm{E}-02$ & $0.0 \mathrm{E}+00$ & $0.0 \mathrm{E}+00$ \\
\hline Recharge & $-1.1 \mathrm{E}+01$ & $-1.3 \mathrm{E}-01$ & $-2.6 \mathrm{E}-02$ & $0.0 \mathrm{E}+00$ & $2.6 \mathrm{E}-02$ \\
\hline Wet & $5.3 \mathrm{E}+00$ & $0.0 \mathrm{E}+00$ & $-2.1 \mathrm{E}-02$ & $0.0 \mathrm{E}+00$ & $1.7 \mathrm{E}-02$ \\
\hline Recession & $4.2 \mathrm{E}+00$ & $1.2 \mathrm{E}-01$ & $-2.5 E-02$ & $9.1 \mathrm{E}-03$ & $0.0 \mathrm{E}+00$ \\
\hline Trend & $\begin{array}{l}\text { PK2 } \\
\left(\mathrm{mm}_{\text {year }}^{-1}\right)\end{array}$ & $\begin{array}{l}\text { PK3 } \\
\left(\mathrm{mm} \mathrm{year}^{-1}\right)\end{array}$ & $\begin{array}{l}\text { PK4 } \\
\left(\mathrm{mm} \mathrm{year}^{-1}\right)\end{array}$ & $\left(1 s^{\text {Qd }}\right.$ year $\left.^{-1}\right)$ & $\begin{array}{l}\text { API8 } \\
\left(\mathrm{mm} \mathrm{year}^{-1}\right)\end{array}$ \\
\hline Overall & $1.2 \mathrm{E}+00$ & $2.6 \mathrm{E}+00$ & $5.2 \mathrm{E}+00$ & $0.0 \mathrm{E}+00$ & $2.1 \mathrm{E}-02$ \\
\hline Recharge & $-3.7 \mathrm{E}+00$ & $-3.6 \mathrm{E}+01$ & $-5.3 \mathrm{E}+00$ & $-4.0 \mathrm{E}-01$ & $1.5 \mathrm{E}-03$ \\
\hline Wet & $1.3 \mathrm{E}+01$ & $9.7 \mathrm{E}+00$ & $7.8 \mathrm{E}+00$ & $1.5 \mathrm{E}+00$ & $9.6 \mathrm{E}-02$ \\
\hline Recession & $6.7 \mathrm{E}-01$ & $-7.1 \mathrm{E}+00$ & $-1.3 \mathrm{E}+01$ & $-3.1 \mathrm{E}-01$ & $8.7 \mathrm{E}-03$ \\
\hline
\end{tabular}

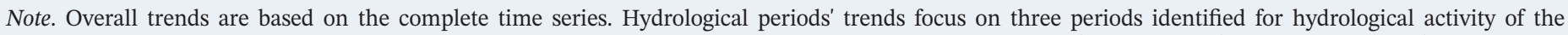

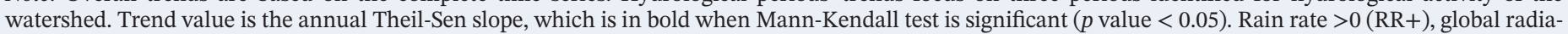

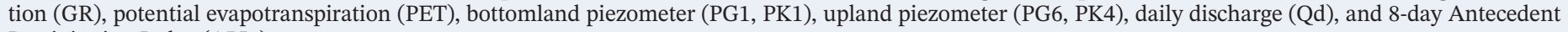
Precipitation Index (API8).

The Mann-Kendall test detected positive trends for API and AirTemp. The overall positive trend for API $\left(0.02 \mathrm{~mm} \cdot \mathrm{year}^{-1}\right)$ was driven most likely by a positive trend during the wet period, while the overall positive trend for AirTemp $\left(0.04^{\circ} \mathrm{C} \cdot\right.$ year $\left.^{-1}\right)$ was driven mostly by a stronger positive trend during the recession period $\left(0.12^{\circ} \mathrm{C} \cdot\right.$ year $\left.^{-1}\right)$ despite having a negative trend during the recharge period $\left(-0.13^{\circ} \mathrm{C} \cdot \mathrm{year}^{-1}\right)$. GR showed a negative trend during the recharge period and a positive one during the wet period. A slight overall negative trend was detected for Wind, with higher slopes during the recession and recharge periods.

Discharge and most piezometers had low or null slopes for overall trends but a negative trend during recharge and recession periods and positive trends during wet periods. Thus, the hydrology was characterized by winters becoming wetter and summers becoming drier. For discharge, the increase during the wet period $\left(1.51 \cdot \mathrm{s}^{-1} \cdot \mathrm{year}^{-1}\right)$ was higher than the decreases during the recharge and recession periods $(-0.4$ and $-0.31 \mathrm{l} \cdot \mathrm{s}^{-1} \cdot$ year $^{-1}$, respectively). The magnitude of overall and seasonal trends varied greatly among piezometers, likely because of differences in their locations (the maximum limited by the soil surface in downslope locations) and depths (4-8 m), which sometimes limited the ability to capture the entire recession.

DOC and $\mathrm{SO}_{4}$ concentrations showed overall positive trends $\left(0.034\right.$ and $0.096 \mathrm{mg} \cdot \mathrm{l}^{-1} \cdot$ year ${ }^{-1}$, respectively), while $\mathrm{Cl}, \mathrm{NO}_{3}$, and SRP concentrations showed overall negative trends $(-0.44,-1.2$, and $-0.0013 \mathrm{mg} \cdot \mathrm{l}^{-1} \cdot \mathrm{year}^{-1}$, respectively). We observed positive trends for DOC concentrations for the wet and recession periods, while $\mathrm{SO}_{4}$ concentrations instead had positive trends for the recharge and recession periods. $\mathrm{NO}_{3}$ and $\mathrm{Cl}$ concentrations showed negative trends during all three hydrological periods.

\subsection{Seasonality}

\subsubsection{Average Seasonal Patterns}

The Fourier series' accordance with the data was high for water table levels, stream discharge, GR, AirTemp, PET, and $\mathrm{NO}_{3}(r>0.6)$; medium for DOC and SRP concentrations $(r=0.47$ and 0.37, respectively, Supporting Information S5); and low for RR, Wind, and API $(r<0.35$, Supporting Information S5). AirTemp and GR showed a clearly periodic seasonal cycle, while Wind and RR showed noisier cycles (Figure 2, Supporting Information S6). Discharge dynamics showed a fast rising limb from October to January/February, followed by a slow recession until the end of the hydrological year. The seasonal signal of upslope piezometers (PK4 and PG5) was similar to that of discharge, while signals of downslope piezometers (PK1 and PG1) had a more rectangular shape. DOC, $\mathrm{SO}_{4}$, and $\mathrm{Cl}$ concentrations peaked in October and November, at the beginning of the hydrological year, then decreased until April/May, and finally rose until the end of the hydrological year. $\mathrm{NO}_{3}$ showed an opposite pattern to DOC, since $\mathrm{NO}_{3}$ concentration was lowest at the beginning of the hydrological year, rose until the end of the wet period in March/April, and then slowly decreased until the end of the hydrological year. SRP showed a more complex pattern, with two peaks: Its concentration decreased from October-December and then peaked first during the wet period in January/February and then again during the dry period in September. 

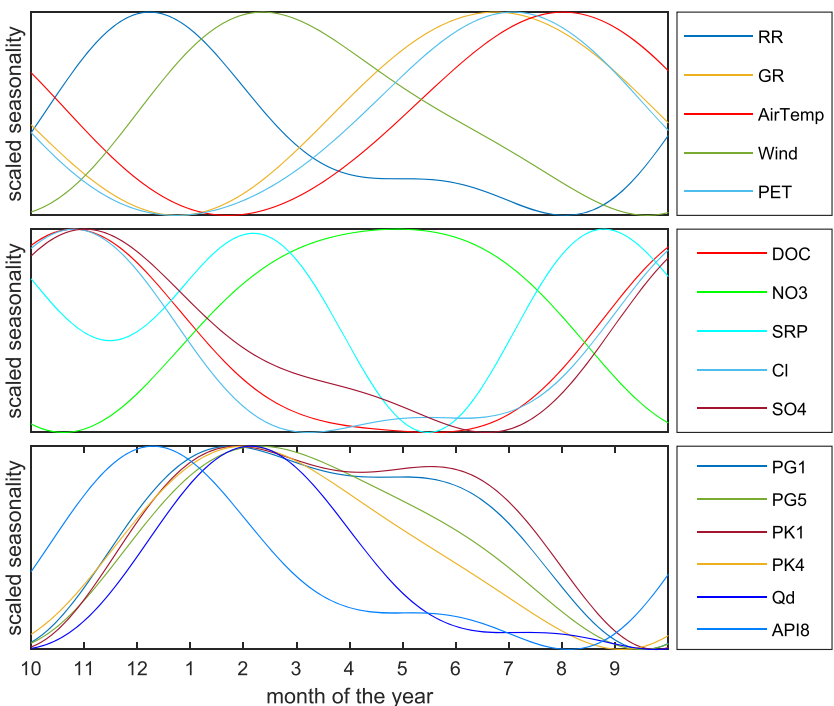

Figure 2. Seasonal patterns of all variables identified by Fourier transforms (two harmonics) for (top panel) rain rate (RR), global radiation (GR), and potential evapotranspiration (PET); (middle panel) DOC, $\mathrm{NO}_{3}, \mathrm{SRP}, \mathrm{Cl}$, and $\mathrm{SO}_{4}$ concentrations; and (bottom panel) bottomland piezometer (PG1, PK1), upland piezometer (PG6, PK4), daily discharge (Qd), and Antecedent Precipitation Index (API).

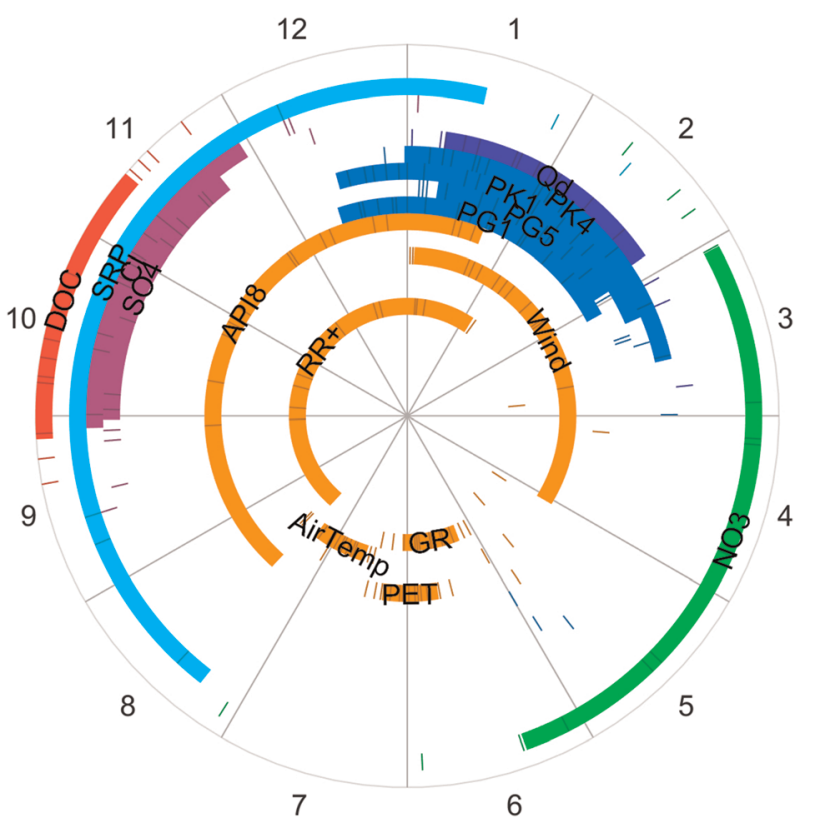

Figure 3. Variability in dates of seasonal peaks of dissolved organic carbon $(\mathrm{DOC})$, nitrate $\left(\mathrm{NO}_{3}\right)$, soluble reactive phosphorus (SRP), discharge (Qd), bottomland piezometer (PG1, PK1), upland piezometer (PG5, PK4), air temperature (AirTemp), wind speed, global radiation (GR), rain rate (RR), and Antecedent Precipitation Index (API). Numbers outside the circle correspond to months. Colored lines are the day of year of the peak amplitude of the seasonality for each hydrological year. The filled area is the mean day of year \pm 1 standard deviation of the peak's annual seasonality.
GR and AirTemp peaked in June and July, respectively, while RR and Wind peaked within wider temporal windows, from November to mid-February and January-March, respectively (Figure 3). The water table in the downslope domain (PG1 and PK1) peaked from DecemberFebruary, slightly before discharge peaked, while in the upslope domain, water table levels peaked from January-February. Discharge peaked from mid-January to the beginning of March. $\mathrm{DOC}, \mathrm{SO}_{4}$, and $\mathrm{Cl}$ concentrations peaked in autumn from the beginning of October to the end of November at the onset of increased discharge. Then, because of its two annual peaks, SRP peaked in September and January. Finally, $\mathrm{NO}_{3}$ concentrations peaked 6 months after the other solutes did, from the end of March to the end of May.

\subsubsection{Interannual Variations}

The seasonal amplitude (Table 2) of DOC was positively correlated with those of RR, PET, bottomland piezometers (PG1, PK1), and $\mathrm{SO}_{4}$. The seasonal amplitude of SRP was positively correlated with those of bottomland piezometers (PG1, PK1), GR, and $\mathrm{Cl}$ and negatively correlated with that of Wind. The seasonal amplitude of $\mathrm{NO}_{3}$ showed low correlations with those of all other variables.

The seasonal phase shift (Table 3) of maximum DOC showed stronger positive correlation with the maxima of bottomland piezometers (PG1, $\mathrm{PK} 1$ ), $\mathrm{SO}_{4}$, and $\mathrm{Cl}$. The seasonal phase shift of maximum $\mathrm{NO}_{3}$ was positively correlated mostly with that of RR. The seasonal phase shift of maximum SRP was positively correlated with the maxima of RR, upland and bottomland piezometers, discharge, $\mathrm{Cl}$, and $\mathrm{SO}_{4}$. Stronger correlations found for SRP may have been due to its shorter time series.

Mean discharge-weighted concentrations of DOC increased and SRP decreased as the length of the preceding dry period increased $(r=0.68$ and -0.49 , respectively), while that of $\mathrm{NO}_{3}$ was unaffected by dry-period length $(r=-0.09)$ (Figure 4$)$. This relationship remained scattered for SRP.

\subsection{Highest and Lowest Concentrations}

As detailed below, the main associations with the extreme concentrations detected differed by hydrological regime, with less co-occurrence of the highest/lowest concentrations and hydroclimatic variables for base flow than stormflow conditions. The highest and lowest DOC and SRP were frequently associated with the same conditions, unlike $\mathrm{NO}_{3}$. Generally, extreme concentrations of $\mathrm{DOC}, \mathrm{NO}_{3}$, and SRP were associated mainly with extreme RR and API, rather than with extreme AirTemp or Wind.

\subsubsection{Base Flow Conditions}

The highest DOC and SRP concentrations and lowest $\mathrm{NO}_{3}$ concentrations co-occurred with the highest API class, and vice versa. The highest $\mathrm{NO}_{3}$ and DOC concentrations co-occurred with the lowest AirTemp classes, and the highest DOC concentrations co-occurred with the lowest GR and PET classes (Figure 5, Supporting Information S7). The highest $\mathrm{NO}_{3}$ concentrations co-occurred with the highest classes of discharge and piezometric levels, while the highest DOC and SRP concentrations showed no trend among classes of discharge or piezometry (Figure 5).

\subsubsection{Stormflow Conditions}

On days with a storm event, the occurrence of the highest DOC and SRP concentrations and the lowest $\mathrm{NO}_{3}$ concentrations increased with the class of API, RR, and, to some extent, Wind (Figure 6), and vice versa 
Table 2

Correlation Matrix of the Ranks of Annual Amplitudes of the Seasonality Identified by Two-Harmonic Fourier Transforms

\begin{tabular}{|c|c|c|c|c|c|c|c|c|c|c|c|c|c|c|c|c|}
\hline Variable & DOC & $\mathrm{NO}_{3}$ & SRP & $\mathrm{Cl}$ & $\mathrm{SO}_{4}$ & $\mathrm{RR}$ & GR & AirT. & Wind & PET & PG1 & PG5 & PK1 & PK4 & Qd & API8 \\
\hline DOC & 1.00 & 0.33 & 0.17 & -0.18 & 0.65 & 0.46 & 0.28 & -0.20 & -0.22 & 0.41 & 0.46 & 0.03 & 0.48 & 0.11 & -0.20 & 0.47 \\
\hline $\mathrm{NO}_{3}$ & 0.33 & 1.00 & -0.36 & -0.13 & 0.31 & 0.26 & 0.00 & 0.04 & 0.01 & -0.03 & -0.01 & -0.12 & 0.16 & 0.00 & -0.01 & 0.26 \\
\hline SRP & 0.17 & -0.36 & 1.00 & 0.51 & 0.03 & 0.11 & 0.43 & -0.28 & -0.55 & 0.18 & 0.62 & 0.49 & 0.59 & 0.48 & 0.35 & 0.11 \\
\hline $\mathrm{RR}$ & 0.46 & 0.26 & 0.11 & 0.32 & 0.21 & 1.00 & 0.24 & 0.05 & 0.24 & 0.37 & 0.28 & 0.50 & 0.24 & 0.73 & 0.58 & 0.99 \\
\hline GR & 0.28 & 0.00 & 0.43 & -0.39 & 0.21 & 0.24 & 1.00 & 0.59 & -0.32 & 0.91 & 0.65 & 0.20 & 0.56 & 0.04 & -0.12 & 0.21 \\
\hline AirTemp & -0.20 & 0.04 & -0.28 & -0.03 & 0.07 & 0.05 & 0.59 & 1.00 & -0.14 & 0.57 & 0.41 & 0.20 & 0.29 & -0.05 & -0.04 & 0.03 \\
\hline PET & 0.41 & -0.03 & 0.18 & -0.25 & 0.36 & 0.37 & 0.91 & 0.57 & -0.08 & 1.00 & 0.69 & 0.25 & 0.54 & 0.14 & -0.11 & 0.36 \\
\hline Qd & -0.20 & -0.01 & 0.35 & 0.56 & -0.36 & 0.58 & -0.12 & -0.04 & 0.26 & -0.11 & -0.15 & 0.54 & -0.22 & 0.84 & 1.00 & 0.59 \\
\hline API8 & 0.47 & 0.26 & 0.11 & 0.35 & 0.19 & 0.99 & 0.21 & 0.03 & 0.26 & 0.36 & 0.25 & 0.49 & 0.21 & 0.73 & 0.59 & 1.00 \\
\hline
\end{tabular}

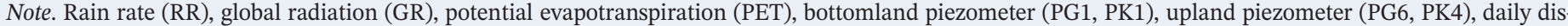
charge (Qd), and 8-day Antecedent Precipitation Index (API8). Bold values exceed 0.40.

(Supporting Information S8), such as for base flow. Note that the days with storm events were expected to be windier. The lowest DOC and SRP concentrations co-occurred with the highest classes of GR and PET, while the lowest $\mathrm{NO}_{3}$ concentrations co-occurred with the lowest classes of GR and PET (Figure 6). The highest SRP concentrations co-occurred only with highest class of daily discharge and piezometric levels, but the highest SRP and DOC concentrations and the lowest $\mathrm{NO}_{3}$ concentrations co-occurred with the highest classes of stormflow peak discharge (Figure 6, Supporting Information S8).

\section{Discussion}

\subsection{Comparison of $\mathrm{C}, \mathrm{N}$, and $\mathrm{P}$ Temporal Patterns}

4.1.1. Opposite DOC and $\mathrm{NO}_{3}$ Patterns From Daily to Decadal Scales

Looking at the three temporal scales, a major result is the opposite $\mathrm{DOC}$ and $\mathrm{NO}_{3}$ dynamics, highlighting that both solutes are controlled by common mechanisms (Heppell et al., 2017; Koenig et al., 2017; Taylor \& Townsend, 2010; Weigand et al., 2017). The long-term decrease in $\mathrm{NO}_{3}$ and increase in DOC can be explained by several nonexclusive factors. The decrease in $\mathrm{NO}_{3}$ is likely a result of past reduction of agricultural pressures that led to a decrease in $\mathrm{NO}_{3}$ storage in the watershed. In piezometers, groundwater $\mathrm{NO}_{3}$ concentrations were observed to decrease from a mean of $109.5 \pm 38.5 \mathrm{mg} \cdot \mathrm{NO}_{3} \cdot \mathrm{l}^{-1}$ in 2000 to $59.3 \pm 30.8 \mathrm{mg} \cdot \mathrm{NO}_{3} \cdot \mathrm{l}^{-1}$ in 2018 along transect $\mathrm{K}$. Despite relatively constant agricultural $\mathrm{N}$ input during the study period, the amounts of $\mathrm{N}$ input likely decreased the most from 1998-2008, due to environmental regulations. The observation that $\mathrm{Cl}$ concentrations, also influenced by fertilization practices (Aubert et al., 2013; Hrachowitz et al., 2015), decreased supports the idea of stock depletion after the past reduction of agricultural pressures. In addition, Goodale et al. (2005) suggested that the long-term decrease in stream $\mathrm{NO}_{3}$ concentrations observed in forested streams in the White Mountains of New Hampshire, USA, could be related to the increase in DOC concentrations, due to either increased denitrification or N immobilization in

Table 3

Correlation Matrix of the Ranks of Annual Phase Shifts of the Seasonality Identified by Two-Harmonic Fourier Transforms

\begin{tabular}{|c|c|c|c|c|c|c|c|c|c|c|c|c|c|c|c|c|}
\hline Variable & DOC & $\mathrm{NO}_{3}$ & SRP & $\mathrm{Cl}$ & $\mathrm{SO}_{4}$ & $\mathrm{RR}$ & GR & AirT. & Wind & PET & PG1 & PG5 & PK1 & PK4 & Qd & API8 \\
\hline DOC & 1.00 & 0.29 & 0.44 & 0.54 & 0.56 & 0.19 & 0.03 & -0.35 & 0.05 & 0.21 & 0.41 & 0.34 & 0.42 & 0.14 & 0.26 & 0.17 \\
\hline $\mathrm{NO}_{3}$ & 0.29 & 1.00 & 0.48 & 0.31 & 0.27 & 0.49 & 0.20 & -0.16 & -0.07 & 0.09 & 0.10 & 0.16 & 0.12 & 0.18 & 0.25 & 0.48 \\
\hline SRP & 0.44 & 0.48 & 1.00 & 0.79 & 0.78 & 0.51 & 0.24 & 0.03 & -0.30 & 0.19 & 0.55 & 0.66 & 0.63 & 0.68 & 0.62 & 0.51 \\
\hline $\mathrm{RR}$ & 0.19 & 0.49 & 0.51 & -0.17 & 0.13 & 1.00 & -0.01 & -0.07 & -0.39 & -0.01 & -0.12 & -0.04 & -0.08 & 0.18 & 0.09 & 1.00 \\
\hline GR & 0.03 & 0.20 & 0.24 & 0.19 & -0.07 & -0.01 & 1.00 & 0.21 & -0.07 & 0.91 & -0.14 & -0.15 & -0.17 & -0.24 & -0.21 & 0.01 \\
\hline AirTemp & -0.35 & -0.16 & 0.03 & -0.16 & -0.01 & -0.07 & 0.21 & 1.00 & 0.00 & 0.22 & 0.12 & 0.05 & 0.08 & -0.11 & -0.15 & -0.05 \\
\hline PET & 0.21 & 0.09 & 0.19 & 0.13 & -0.07 & -0.01 & 0.91 & 0.22 & -0.06 & 1.00 & -0.06 & -0.08 & -0.10 & -0.22 & -0.15 & 0.00 \\
\hline Qd & 0.26 & 0.25 & 0.62 & 0.31 & 0.44 & 0.09 & -0.21 & -0.15 & -0.04 & -0.15 & 0.59 & 0.83 & 0.64 & 0.86 & 1.00 & 0.07 \\
\hline API8 & 0.17 & 0.48 & 0.51 & -0.19 & 0.13 & 1.00 & 0.01 & -0.05 & -0.43 & 0.00 & -0.12 & -0.05 & -0.08 & 0.19 & 0.07 & 1.00 \\
\hline
\end{tabular}

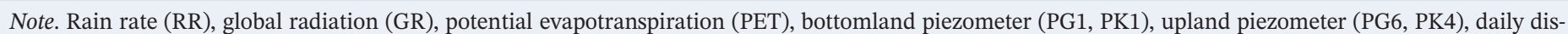
charge (Qd), and 8-day Antecedent Precipitation Index (API8). Bold values exceed 0.40. 

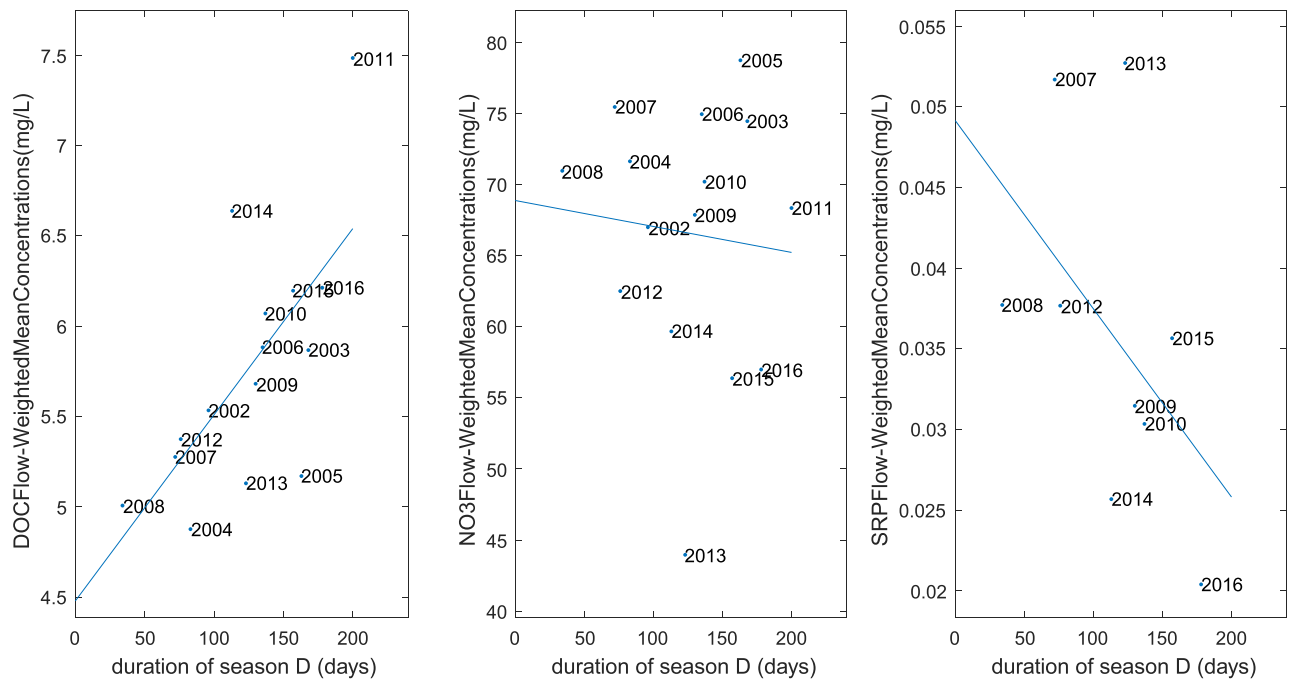

Figure 4. Discharge weighted-mean dissolved organic carbon (DOC) (left), nitrate $\left(\mathrm{NO}_{3}\right)$ (middle), and soluble reactive phosphorus (SRP) (right) concentrations as a function of the duration of the dry period (Season D), during which the stream is disconnected from the surface soil horizon. Note that fewer years were available for SRP than DOC and $\mathrm{NO}_{3}$.

soils or sediments. In the Kervidy-Naizin agricultural ecosystem, $\mathrm{N}$ availability is far higher than that in seminatural ecosystems, but similar relationships are expected. Salmon-Monviola et al. (2013), in a modeling study of the Kervidy-Naizin watershed, predicted an increase in denitrification under climate change scenarios, not only in wetlands but also in upland areas. In upland, areas of denitrification expanded because of greater $\mathrm{NO}_{3}$ availability due to more mineralization (temperature effect) and less leaching (precipitation effect). In near-stream wetlands, both warming and increased frequency of aerobic-anaerobic cycles increased denitrification rates due to greater variability in precipitation. Thus, climate may help explain the $\mathrm{NO}_{3}$ trend through a combination of favorable conditions of temperature and water supply, which also influenced the release of DOC driven by reductive reactions (Grybos et al., 2009), since these mechanisms

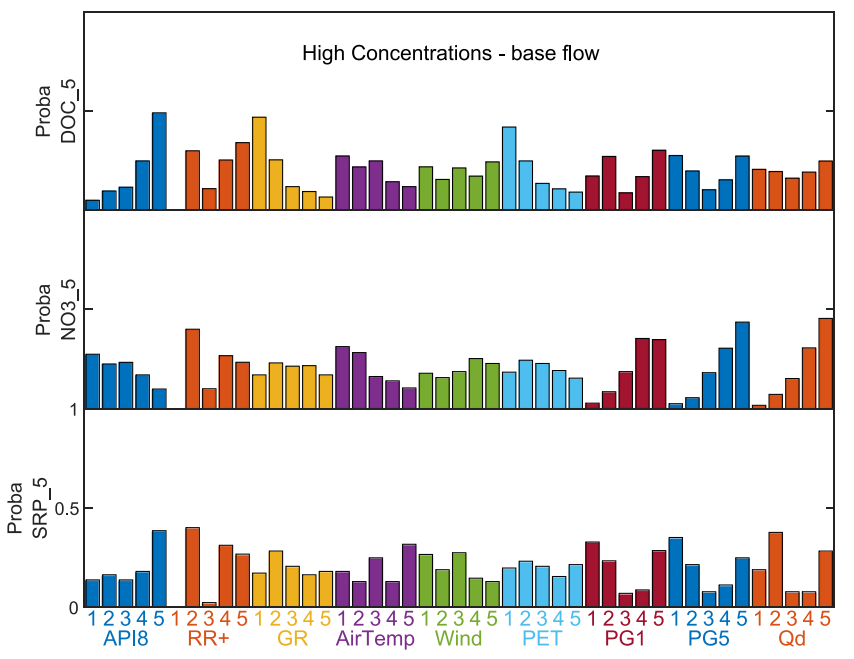

Figure 5. Distributions of hydrological and meteorological classes for the highest concentrations of dissolved organic carbon (DOC), nitrate $\left(\mathrm{NO}_{3}\right)$, and soluble reactive phosphorus (SRP) during base flow. Rain rate $>0$ $(\mathrm{RR}+)$, global radiation (GR), air temperature (AirTemp), potential evapotranspiration (PET), bottomland piezometer (PG1), upland piezometer (PG5), daily discharge (Qd), and Antecedent Precipitation Index (API). are interrelated in time and space. In addition, the increase in winter flow and storm event frequency, which would increase surface runoff and overland flow, rich in DOC and poor in $\mathrm{NO}_{3}$, could also partly explain the long-term decrease in $\mathrm{NO}_{3}$ concentrations and increase in DOC concentrations (Mellander et al., 2018). Storm event frequency varied greatly from 2002-2017 and seemed to increase slightly during the study period (TS slope: 0.54 storm events per year), though the sample size $(n=16)$ was too small to extract a significant trend according to the Mann-Kendall test. Finally, like DOC concentrations, $\mathrm{SO}_{4}$ concentrations increased slightly, which could be explained either by partial reoxidation of the sulfur stored in organic-rich riparian soil (Eimers et al., 2007) during winter flow periods or by a slightly increased contribution of $\mathrm{SO}_{4}$-rich deep groundwater to the stream (Morel et al., 2009).

The seasonal opposition observed between $\mathrm{DOC}$ and $\mathrm{NO}_{3}$ resulted in part from the mixing of three end-member compartments with different water transmissivities and concentrations (Fovet et al., 2015; Molenat et al., 2002; Ruiz et al., 2002). Indeed, in the Kervidy-Naizin watershed, surface soil horizons and near-stream areas have higher OM contents and lower $\mathrm{NO}_{3}$ concentrations than deeper water or upslope areas (Aubert et al., 2013). Maximum DOC ( $\mathrm{Cl}$ and $\left.\mathrm{SO}_{4}\right)$ and minimum $\mathrm{NO}_{3}$ concentrations occurred in autumn, when downslope soils (DOC-rich, $\mathrm{NO}_{3}$-poor) contributed more water to streams than hillslope groundwater did. As the water table rose during autumn, $\mathrm{DOC}$ and $\mathrm{NO}_{3}$ concentrations 


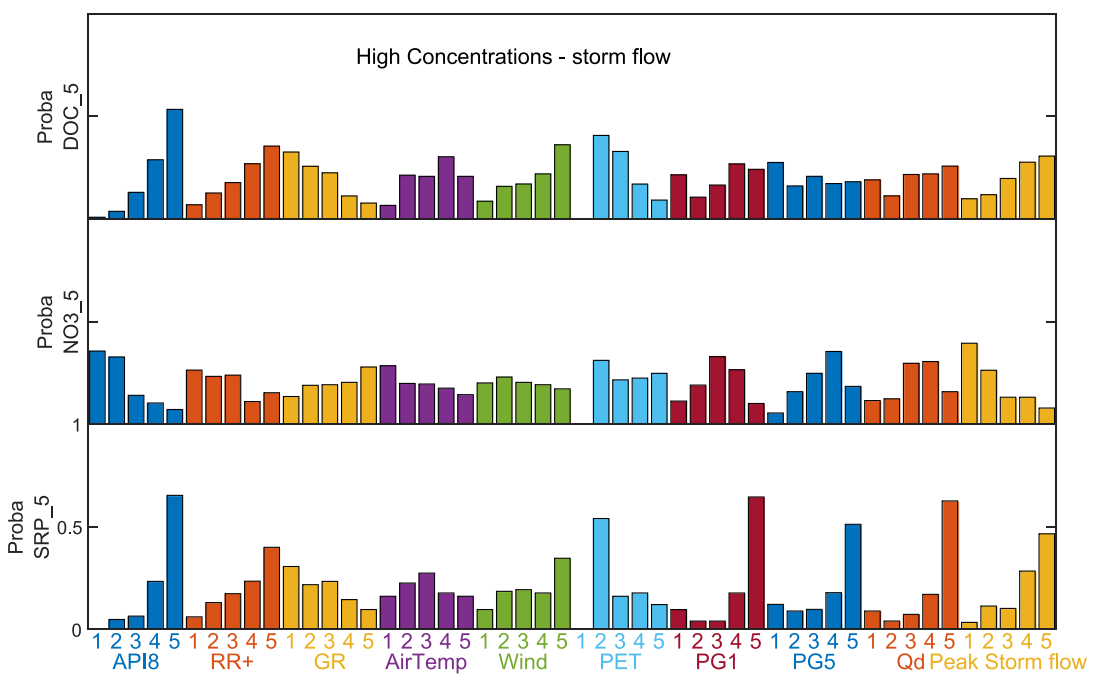

Figure 6. Distributions of hydrological and meteorological classes for the highest concentrations of dissolved organic carbon (DOC), nitrate $\left(\mathrm{NO}_{3}\right)$, and soluble reactive phosphorus (SRP) during stormflow. Rain rate $>0$ (RR+), global radiation (GR), air temperature (AirTemp), potential evapotranspiration (PET), bottomland piezometer (PG1), upland piezometer (PG5), daily discharge (Qd), and Antecedent Precipitation Index (API).

decreased and increased, respectively, because the contribution from upland groundwater ( $1.5 \mathrm{mg} \cdot \mathrm{DOC} \cdot \mathrm{l}^{-1}$, Morel, 2009; and $90 \mathrm{mg} \cdot \mathrm{NO}_{3} \cdot \mathrm{l}^{-1}$, Aubert et al., 2013) increased. During low flow in summer, DOC and $\mathrm{NO}_{3}$ concentrations continued to increase and decrease, respectively, while deep groundwater supplied nearly all water to the stream. Thus, some production/mobilization processes associated with $\mathrm{NO}_{3}$ consumption and DOC production are likely to occur in near-stream or in-stream areas during this period (Arango et al., 2007; Barnes \& Raymond, 2010; Bernhardt \& Likens, 2002). DOC concentrations peaked under wet or stormflow conditions, when $\mathrm{NO}_{3}$ concentrations were lowest. In contrast, $\mathrm{NO}_{3}$ concentrations peaked under high-water-table and drier conditions, when DOC concentrations were lowest. This opposition between maxima and minima of daily DOC and $\mathrm{NO}_{3}$ concentrations can also be interpreted as the result of relative mixing contributions. These contributions of soil-surface riparian flows, DOC-rich and $\mathrm{NO}_{3}$-poor, and upslope groundwater flows, $\mathrm{NO}_{3}$-rich and DOC-poor (Aubert et al., 2013), vary more during stormflow than base flow, which explains the clearer co-occurrences for the first regime.

Thus, at all three temporal scales, the hydrological mechanisms involved are the relative mixing of hydrological flow paths (Heppell et al., 2017; Weigand et al., 2017) that express opposite vertical or lateral spatial gradients of $\mathrm{C}$ and $\mathrm{N}$ sources via variations in their hydrological connectivity (Covino, 2017) (Figure 7). The biogeochemical processes invoked involve connections between $\mathrm{N}$ and $\mathrm{C}$ cycles. They include soil mineralization of OM, denitrification and immobilization by heterotrophic microbes in near- or in-stream areas rich in $\mathrm{OM}$ (Boano et al., 2014), and $\mathrm{NO}_{3}$ reduction associated with Fe redox transformations in soils that can lead to DOC and SRP release into the soil solution (Grybos et al., 2009; Gu et al., 2019) (Figure 7). Near-stream and in-stream areas include the water column, streambed, and hyporheic zone, though our data did not allow us to identify which one was the most reactive. The location of $\mathrm{C}$ and $\mathrm{N}$ sources depends on biogeochemical properties and agricultural pressures. In return, hydrological connectivity influences not only the transport, but also the cycling and transformation, of $\mathrm{C}$ and nutrients through the watershed (Covino, 2017). This opposition between $\mathrm{DOC}$ and $\mathrm{NO}_{3}$ dynamics suggests that changes in temperature, wetness, or hydrological flow paths are likely to drive changes in both concentrations but also in their seasonal and event dynamics, with opposite responses of $\mathrm{DOC}$ and $\mathrm{NO}_{3}$, and thus greater response of stream DOC: $\mathrm{NO}_{3}$ ratios.

\subsubsection{Singularity of SRP Dynamics}

Long-term trends in P concentration were difficult to interpret since the corresponding time series were shorter and varied in frequency (every 3 days at first, then daily). Several studies on larger watersheds also 


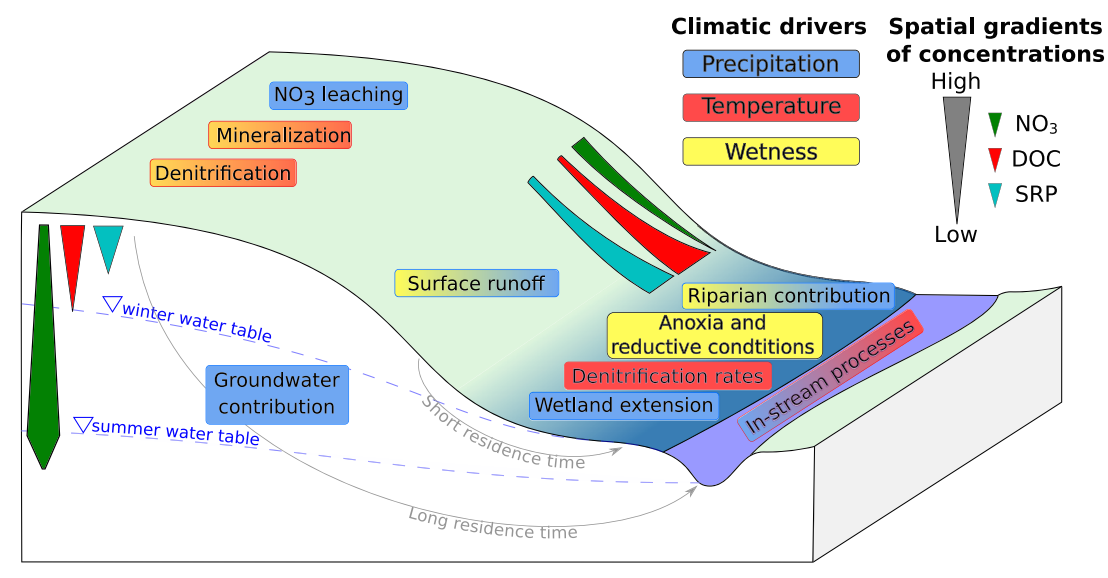

Figure 7. Conceptual model of climate controls on C, N, and P processes and export at the hillslope scale.

reported a decreasing trend in SRP concentrations, related mainly to a decrease in the number of point sources (Bowes et al., 2011; Minaudo et al., 2015). This trend was not expected, since the studied watershed contains only a few farms, which have individual septic tanks.

SRP concentration showed two distinct peaks of seasonality. Timing of the first peak (in February) was correlated with the timing of annual peaks in water table level, after a period of soil water saturation. This first peak occurred when the water table reaches the surface soil horizons enriched in P (Dupas, Gascuel-Odoux, et al., 2015; Gu et al., 2017). Soil water monitoring emphasized an increase in SRP concentration after 12 months of soil saturation (Dupas, Gascuel-Odoux, et al., 2015; Gu et al., 2017). Long periods of soil saturation and warmer temperatures may increase mobilization of SRP adsorbed on soil aggregates due to reduction of soil Fe-oxyhydroxides (Dupas, Gruau, et al., 2015; Dupas et al., 2016; Gu et al., 2018, 2019, 2017) (Figure 7). This mechanism cannot account for the second peak, in summer, since the surface soil horizons were no longer saturated nor hydrologically connected to the stream at that time. This second peak was most likely due to in-stream processes that involved either P mineralization or release from streambed sediments and the hyporheic zone (Boano et al., 2014).

From field and experimental studies, a release of DOC into soil solutions under anoxic conditions was also emphasized and related primarily to the increase in pH caused by reduction reactions (Grybos et al., 2009). Thus, a winter increase in stream DOC concentration similar to the first peak in SRP was expected. However, no such increase was observed in the present time series, which might suggest consumption of DOC between riparian sources and the stream or preferential adsorption on DOC on the soil solid phase at the riparian soil-stream interface (Boano et al., 2014).

Maximum daily SRP concentrations during storm days were driven by rain-discharge events and the hydrological state of the watershed (highest values of daily RR, API, discharge, and piezometric level), which was similar for DOC concentrations. Maximum daily SRP concentrations during base flow showed little relationship with hydroclimatic variable classes except API, which might have been due to the nature of the processes that mobilize SRP, such as surface and subsurface flow that occur only during hydrological events.

\subsection{Climatic Drivers of Stream Concentration Dynamics}

The trend analysis showed a small overall increase in AirTemp but stable precipitation and GR, in accordance with findings of Borg and Sundbom (2014) and Oni et al. (2013) in western Europe. Nonetheless, the magnitude of the mean increase in AirTemp $\left(<0.04^{\circ} \mathrm{C} \cdot\right.$ year $\left.^{-1}\right)$ was much lower than annual thermal fluctuations $\left(8.11^{\circ} \mathrm{C}\right)$. It also suggested that climate change would influence primarily the seasonal distribution of hydroclimatic variations, which is likely to intensify both wet and dry periods, in line with previous studies (Chang et al., 2001; Gombault et al., 2015; Salmon-Monviola et al., 2013; Wang et al., 2018), or increase storm event frequency (not significant). Disentangling the human (agricultural) and climatic drivers of concentration trends was not possible here, but their respective effects appeared to be synergistic. The seasonally opposite variations in precipitation and PET control the recharge of shallow groundwater, 
which delivers 80-90\% of stream flow (Aubert et al., 2013; Lambert et al., 2013; Molenat et al., 2002). High precipitation and low PET in autumn fills the water table, which then feeds the stream. The average pattern of hydrological seasonality identified by the Fourier series agrees with knowledge about water cycles in temperate watersheds dominated by a shallow water table (Miguez-Macho \& Fan, 2012). The lengths of the four hydrological periods (recharge, wet, recession, and dry) showed significant interannual variability, although the time series (16 years from 2002-2017) was too short to reveal a significant trend (Supporting Information S9). Changes in these hydrological periods could be a major driver of changes in water quality (Figure 7).

The fact that the stream in the Kervidy-Naizin watershed dries out completely almost every summer for up to 4 months is a strong feature of its seasonal functioning. Intermittence has been shown to influence microbial processes due to rewetting of accumulated material in the dry channel (Covino, 2017; Datry et al., 2018), which is likely to influence $\mathrm{C}$ emissions from streams significantly (Marcé et al., 2018), especially in temperate climates. The increase in dry-period frequency is also likely to increase mobilization of $\mathrm{P}$ from the land during rewetting events (Forber et al., 2017). The positive effect of dry-period length on mean annual DOC concentration of the following hydrological year confirms the same observation during a shorter period by Humbert et al. (2015). Its negative effect on SRP concentration was unexpected, however, because we assumed that it had the same relationship as it did with DOC. Indeed, SRP and DOC are assumed to have the same riparian origin in this watershed and are also known to respond to alternating wet and dry periods (Gu et al., 2018). Given the difficulty in capturing stream concentrations at the very beginning of the rewetting, special sampling effort focused on this period could help understand effects of dry-period length on biogeochemical cycles better. Rapid immobilization of SRP released during rewetting by being consumed or adsorbed on bed sediments may contribute to the lack of a positive relationship between SRP concentration and dry-period length.

The response of daily concentrations differed between base flow and stormflow periods. For instance, peak $\mathrm{NO}_{3}$ concentrations were associated with the highest base flow, while minimum $\mathrm{NO}_{3}$ concentrations were associated with the highest stormflow. The opposite dynamics of $\mathrm{NO}_{3}$ versus DOC and SRP concentrations were amplified during stormflow. Vautard and Yiou (2009) highlighted an increase in the amount of precipitation per event but no increase in the number of events in western Europe. In the study site, the number of events increased nonsignificantly, but changes in the intensity of storm events could influence stormflow extremes, since peak storm discharge was associated with the highest SRP and DOC concentrations and lowest $\mathrm{NO}_{3}$ concentrations.

Of all variables, API had the most influence at all temporal scales, regardless of the flow conditions or solute, with similar dynamics with DOC and SRP concentrations and opposite dynamics with $\mathrm{NO}_{3}$ concentrations. API is a proxy of both soil wetness, which controls biogeochemical transformation of soil nutrients, and of the relative contribution of surface water flows in the watershed (Newcomer et al., 2018) (Figure 7).

To extend the analysis over climatic gradients, the methodological approach developed in this study could be applied to other observatories of the critical zone. These observatories can monitor multielement concentrations with sufficient temporal frequency to investigate storm dynamics that are key for several elements (e.g., P) and seasonal cycles that can help understand the processes that control solute sources, mobilization, and transfer and thus help reveal their responses to changing climatic regimes (Koenig et al., 2017).

\section{Conclusions}

To identify effects of climate drivers on solute concentrations, we analyzed the coevolution of hydroclimatic variables and $\mathrm{DOC}, \mathrm{NO}_{3}$, and SRP concentrations with a set of methods adapted to different temporal scales of interest. Benefiting from research observatories that collect large amounts of environmental data, the analysis was based on a 16-year time series of daily data from a temperate agro-hydrological observatory dominated by a shallow water table.

Over the 16 years, the climate trends identified were increases in air temperature and hydrological contrast among seasons (wetter winters and drier summers). The length of hydrological periods varied but showed no significant trend, and the number of storm events seemed to increase (nonsignificant). As reported for other 
watersheds, water-quality trends were identified: $\mathrm{NO}_{3}$ concentrations decreased, while DOC concentrations increased. Climate and past agricultural changes seem to have a synergistic effect on long-term responses of stream water concentrations by combining more intense winter water export and biogeochemical reactions with lower agriculture pressure.

For the three solutes, the dynamics of stream water concentrations among seasons and events are more sensitive to dynamics of precipitation and hydrological variables than to those of air temperature or global radiation. The main driving variable is a proxy of watershed wetness (API). Overall, the water-quality response appears to vary less than hydroclimatic variables do, which may be related to legacy stocks in this watershed or to the fact that the climate remains temperate, despite its detected trends.

The integrated analysis of DOC, $\mathrm{NO}_{3}$, and SRP highlighted the opposition of dynamics of $\mathrm{DOC}$ and $\mathrm{NO}_{3}$ concentrations due to opposition in their spatial sources and opposite effects of biogeochemical processes that act at all of these temporal scales. In contrast, the dynamics of SRP concentrations at the outlet were decoupled from those of DOC and $\mathrm{NO}_{3}$ concentrations, since SRP concentrations were controlled more by storms and wetness conditions. The set of methods developed would be useful for other observatories worldwide for similar types of data, offering an important perspective for regional or global analyses based on small networks of research observatories.

\section{Data Availability Statement}

All AgrHyS data are available on the Internet: https://www6.inra.fr/ore_agrhys_eng/Data.

\section{Acknowledgments}

The French National Research Institute for Agriculture, Food and Environment (INRAE) and the Bretagne Region cofunded the doctoral program of L. S. The AgrHyS Observatory is supported by INRAE (UMR SAS, 2010). Carbon and anion concentrations were measured at the Géosciences Rennes laboratory. We thank Laurence Carteaux and Nicolas Gilliet for the phosphorus analyses performed at the UMR SAS laboratory. We are grateful to Jean-Paul Guillard for his precious help with sampling on the Kervidy-Naizin watershed over the years and to all the farmers of Naizin-Évellys for hosting our observations, sampling, and surveys.

\section{References}

Abbott, B. W., Moatar, F., Gauthier, O., Fovet, O., Antoine, V., \& Ragueneau, O. (2018). Trends and seasonality of river nutrients in agricultural catchments: 18 years of weekly citizen science in France. Science Total of Environment, 624, 845-858 https://doi.org/10.1016/j. scitotenv.2017.12.176.

Aquilina, L., Poszwa, A., Walter, C., Vergnaud, V., Pierson-Wickmann, A.-C., \& Ruiz, L. (2012). Long-term effects of high nitrogen loads on cation and carbon riverine export in agricultural catchments. Environmental Science \& Technology, 46(17), 9447-9455.

Arango, C. P., Tank, J. L., Schaller, J. L., Royer, T. V., Bernot, M. J., \& David, M. B. (2007). Benthic organic carbon influences denitrification in streams with high nitrate concentration. Freshwater Biology, 52(7), 1210-1222.

Aubert, A. H., Gascuel-Odoux, C., Gruau, G., Akkal, N., Faucheux, M., Fauvel, Y., et al. (2013). Solute transport dynamics in small, shallow groundwater-dominated agricultural catchments: Insights from a high-frequency, multisolute 10 yr-long monitoring study. Hydrology and Earth System Sciences, 17(4), 1379-1391. https://doi.org/10.5194/hess-17-1379-2013

Barnes, R. T., \& Raymond, P. A. (2010). Land-use controls on sources and processing of nitrate in small watersheds: Insights from dual isotopic analysis. Ecological Applications, 20(7), 1961-1978.

Bartolai, A. M., He, L., Hurst, A. E., Mortsch, L., Paehlke, R., \& Scavia, D. (2015). Climate change as a driver of change in the Great Lakes St. Lawrence River basin. Journal of Great Lakes Research, 41, 45-58.

Basu, N. B., Destouni, G., Jawitz, J. W., Thompson, S. E., Loukinova, N. V., Darracq, A., et al. (2010). Nutrient loads exported from managed catchments reveal emergent biogeochemical stationarity. Geophysical Research Letters, 37, L23404. https://doi.org/10.1029/ 2010GL045168

Basu, N. B., Thompson, S. E., \& Rao, P. S. C. (2011). Hydrologic and biogeochemical functioning of intensively managed catchments: A synthesis of top-down analyses. Water Resources Research, 47, W00J15. https://doi.org/10.1029/2011WR010800

Bennett, E. M., Carpenter, S. R., \& Caraco, N. F. (2001). Human impact on erodable phosphorus and eutrophication: A global perspective: Increasing accumulation of phosphorus in soil threatens rivers, lakes, and coastal oceans with eutrophication. BioScience, 51(3), 227-234.

Bernhardt, E. S., \& Likens, G. E. (2002). Dissolved organic carbon enrichment alters nitrogen dynamics in a forest stream. Ecology, 83(6), $1689-1700$.

Boano, F., Harvey, J. W., Marion, A., Packman, A. I., Revelli, R., Ridolfi, L., \& Wörman, A. (2014). Hyporheic flow and transport processes: Mechanisms, models, and biogeochemical implications. Reviews of Geophysics, 52, 603-679. https://doi.org/10.1002/2012RG000417

Borg, H., \& Sundbom, M. (2014). Long-term trends of water chemistry in mountain streams in Sweden-Slow recovery from acidification. Biogeosciences, 11(1), 173-184.

Bowes, M., Jarvie, H., Halliday, S. J., Skeffington, R., Wade, A., Loewenthal, M., et al. (2015). Characterising phosphorus and nitrate inputs to a rural river using high-frequency concentration-flow relationships. Science Total of Environment, 511, 608-620.

Bowes, M., Smith, J., Neal, C., Leach, D., Scarlett, P., Wickham, H., et al. (2011). Changes in water quality of the River Frome (UK) from 1965 to 2009: Is phosphorus mitigation finally working? Science Total of Environment, 409(18), 3418-3430.

Carluer, N. (1998). Vers une modélisation hydrologique adaptée à l'évaluation des pollutions diffuses: prise en compte du réseau anthropique. Application au bassin versant de Naizin (Morbihan), Paris 6.

Casal, L., Durand, P., Akkal-Corfini, N., Benhamou, C., Laurent, F., Salmon-Monviola, J., et al. (2019). Reduction of stream nitrate concentrations by land management in contrasted landscapes. Nutrient Cycling in Agroecosystems, 114(1), 1-17.

Chang, H., Evans, B. M., \& Easterling, D. R. (2001). The effects of climate change on stream flow and nutrient loading 1. JAWRA Journal of the American Water Resources Association, 37(4), 973-985.

Cheverry, C. (1998). Agriculture intensive et qualité des eaux, Editions Quae.

Covino, T. (2017). Hydrologic connectivity as a framework for understanding biogeochemical flux through watersheds and along fluvial networks. Geomorphology, 277, 133-144. 
Datry, T., Foulquier, A., Corti, R., von Schiller, D., Tockner, K., Mendoza-Lera, C., et al. (2018). A global analysis of terrestrial plant litter dynamics in non-perennial waterways. Nature Geoscience, 11(7), 497-503. https://doi.org/10.1038/s41561-018-0134-4

Davis, C. A., Ward, A. S., Burgin, A. J., Loecke, T. D., Riveros-Iregui, D. A., Schnoebelen, D. J., et al. (2014). Antecedent moisture controls on stream nitrate flux in an agricultural watershed. Journal of Environmental Quality, 43(4), 1494-1503.

Delpla, I., Jung, A. V., Baures, E., Clement, M., \& Thomas, O. (2009). Impacts of climate change on surface water quality in relation to drinking water production. Environment International, 35(8), 1225-1233.

Dick, J., Tetzlaff, D., Birkel, C., \& Soulsby, C. (2015). Modelling landscape controls on dissolved organic carbon sources and fluxes to streams. Biogeochemistry, 122(2-3), 361-374.

Dupas, R., Gascuel-Odoux, C., Gilliet, N., Grimaldi, C., \& Gruau, G. (2015). Distinct export dynamics for dissolved and particulate phosphorus reveal independent transport mechanisms in an arable headwater catchment. Hydrological Processes, 29(14), $3162-3178$.

Dupas, R., Gruau, G., Gu, S., Humbert, G., Jaffrezic, A., \& Gascuel-Odoux, C. (2015). Groundwater control of biogeochemical processes causing phosphorus release from riparian wetlands. Water Research, 84, 307-314. https://doi.org/10.1016/j. watres.2015.07.048

Dupas, R., Minaudo, C., Gruau, G., Ruiz, L., \& Gascuel-Odoux, C. (2018). Multidecadal trajectory of riverine nitrogen and phosphorus dynamics in rural catchments. Water Resources Research, 54, 5327-5340. https://doi.org/10.1029/2018WR022905

Dupas, R., Salmon-Monviola, J., Beven, K. J., Durand, P., Haygarth, P. M., Hollaway, M. J., \& Gascuel-Odoux, C. (2016). Uncertainty assessment of a dominant-process catchment model of dissolved phosphorus transfer. Hydrology and Earth System Sciences, 20(12), 4819-4835.

Dupas, R., Tavenard, R., Fovet, O., Gilliet, N., Grimaldi, C., \& Gascuel-Odoux, C. (2015). Identifying seasonal patterns of phosphorus storm dynamics with dynamic time warping. Water Resources Research, 51, 8868-8882. https://doi.org/10.1002/2015WR017338

Dupas, R., Tittel, J., Jordan, P., Musolff, A., \& Rode, M. (2018). Non-domestic phosphorus release in rivers during low-flow: Mechanisms and implications for sources identification. Journal of Hydrology, 560, 141-149.

Eimers, M. C., Watmough, S. A., Buttle, J. M., \& Dillon, P. J. (2007). Drought-induced sulphate release from a wetland in south-central Ontario. Environmental Monitoring and Assessment, 127(1-3), 399-407.

Forber, K. J., Ockenden, M. C., Wearing, C., Hollaway, M. J., Falloon, P. D., Kahana, R., et al. (2017). Determining the effect of drying time on phosphorus solubilization from three agricultural soils under climate change scenarios. Journal of Environmental Quality, 46(5), 1131-1136.

Ford, W. I., King, K., \& Williams, M. R. (2018). Upland and in-stream controls on baseflow nutrient dynamics in tile-drained agroecosystem watersheds. Journal of Hydrology, 556, 800-812.

Fovet, O., Humbert, G., Dupas, R., Gascuel-Odoux, C., Gruau, G., Jaffrezic, A., et al. (2018). Seasonal variability of stream water quality response to storm events captured using high-frequency and multi-parameter data. Journal of Hydrology, 559, 282-293. https://doi.org/ 10.1016/j.jhydrol.2018.02.040

Fovet, O., Ruiz, L., Faucheux, M., Molénat, J., Sekhar, M., Vertès, F., et al. (2015). Using long time series of agricultural-derived nitrates for estimating catchment transit times. Journal of Hydrology, 522, 603-617.

Fovet, O., Ruiz, L., Gruau, G., Akkal, N., Aquilina, L., Busnot, S., et al. (2018). AgrHyS: An observatory of response times in agro-hydro systems. Vadose Zone Journal, 17(1), 180066. https://doi.org/10.2136/vzj2018.04.0066

Gaillardet, J., Braud, I., Hankard, F., Anquetin, S., Bour, O., Dorfliger, N., et al. (2018). OZCAR: The French Network of Critical Zone Observatories. Vadose Zone Journal, 17(1), 180067. https://doi.org/10.2136/vzj2018.04.0067

Galloway, J. N., \& Cowling, E. B. (2002). Reactive nitrogen and the world: 200 years of change. Ambio: A Journal of the Human Environment, 31(2), 64-72.

Gascuel-Odoux, C., Aurousseau, P., Durand, P., Ruiz, L., \& Molenat, J. (2010). The role of climate on inter-annual variation in stream nitrate fluxes and concentrations. Science Total of Environment, 408(23), 5657-5666.

Gascuel-Odoux, C., Fovet, O., Gruau, G., Ruiz, L., \& Merot, P. (2018). Evolution of scientific questions over 50 years in the Kervidy-Naizin catchment: From catchment hydrology to integrated studies of biogeochemical cycles and agroecosystems in a rural landscape. Cuadernos de Investigación Geográfica, 44(2), 535-555.

Gombault, C., Sottile, M.-F., Ngwa, F. F., Madramootoo, C. A., Michaud, A. R., Beaudin, I., \& Chikhaoui, M. (2015). Modelling climate change impacts on the hydrology of an agricultural watershed in southern Québec. Canadian Water Resources Journal/Revue canadienne des ressources hydriques, 40(1), 71-86.

Goodale, C. L., Aber, J. D., Vitousek, P. M., \& McDowell, W. H. (2005). Long-term decreases in stream nitrate: Successional causes unlikely; possible links to DOC? Ecosystems, 8(3), 334-337.

Green, C. T., Bekins, B. A., Kalkhoff, S. J., Hirsch, R. M., Liao, L., \& Barnes, K. K. (2014). Decadal surface water quality trends under variable climate, land use, and hydrogeochemical setting in Iowa, USA. Water Resources Research, 50, 2425-2443. https://doi.org/ 10.1002/2013WR014829

Grybos, M., Davranche, M., Gruau, G., Petitjean, P., \& Pédrot, M. (2009). Increasing pH drives organic matter solubilization from wetland soils under reducing conditions. Geoderma, 154(1-2), 13-19.

Gu, S., Gruau, G., Dupas, R., Petitjean, P., Li, Q., \& Pinay, G. (2019). Respective roles of Fe-oxyhydroxide dissolution, pH changes and sediment inputs in dissolved phosphorus release from wetland soils under anoxic conditions. Geoderma, 338, 365-374.

Gu, S., Gruau, G., Dupas, R., Rumpel, C., Creme, A., Fovet, O., et al. (2017). Release of dissolved phosphorus from riparian wetlands: Evidence for complex interactions among hydroclimate variability, topography and soil properties. Science Total of Environment, 598, 421-431.

Gu, S., Gruau, G., Malique, F., Dupas, R., Petitjean, P., \& Gascuel-Odoux, C. (2018). Drying/rewetting cycles stimulate release of colloidal-bound phosphorus in riparian soils. Geoderma, 321, 32-41.

Halliday, S. J., Wade, A. J., Skeffington, R. A., Neal, C., Reynolds, B., Rowland, P., et al. (2012). An analysis of long-term trends, seasonality and short-term dynamics in water quality data from Plynlimon, Wales. Science Total of Environment, 434, $186-200$.

He, T., Lu, Y., Cui, Y., Luo, Y., Wang, M., Meng, W., et al. (2015). Detecting gradual and abrupt changes in water quality time series in response to regional payment programs for watershed services in an agricultural area. Journal of Hydrology, 525, $457-471$.

Heppell, C. M., Binley, A., Trimmer, M., Darch, T., Jones, A., Malone, E., et al. (2017). Hydrological controls on DOC: Nitrate resource stoichiometry in a lowland, agricultural catchment, southern UK. Hydrology and Earth System Sciences, 21(9), 4785-4802.

Howden, N., Burt, T., Worrall, F., Whelan, M., \& Bieroza, M. (2010). Nitrate concentrations and fluxes in the River Thames over 140 years (1868-2008): Are increases irreversible? Hydrological Processes, 24(18), 2657-2662. 
Hrachowitz, M., Fovet, O., Ruiz, L., \& Savenije, H. H. G. (2015). Transit time distributions, legacy contamination and variability in biogeochemical 1/f (alpha) scaling: How are hydrological response dynamics linked to water quality at the catchment scale? Hydrological Processes, 29(25), 5241-5256.

Humbert, G., Jaffrezic, A., Fovet, O., Gruau, G., \& Durand, P. (2015). Dry-season length and runoff control annual variability in stream DOC dynamics in a small, shallow groundwater-dominated agricultural watershed. Water Resources Research, 51, 7860-7877. https:// doi.org/10.1002/2015WR017336

ISO 10304, N. (1995). Determination of dissolved fluoride, chloride, nitrite, orthophosphate, bromide, nitrate, and sulfate ions, using liquid chromatography of ions, edited by AFNOR.

ISO 15681, N. (2005). Determination of orthophosphates and total phosphorus contents by flow analysis (FIA and CFA), edited by AFNOR

Kędra, M., Wiejaczka, Ł., \& Wesoły, K. (2016). The role of reservoirs in shaping the dominant cyclicity and energy of mountain river flows. River Research and Applications, 32(4), 561-571.

Koenig, L. E., Shattuck, M. D., Snyder, L. E., Potter, J. D., \& McDowell, W. H. (2017). Deconstructing the effects of flow on DOC, nitrate, and major ion interactions using a high-frequency aquatic sensor network. Water Resources Research, 53, 10,655-10,673. https://doi.org/ 10.1002/2017WR020739

Lambert, T., Pierson-Wickmann, A. C., Gruau, G., Jaffrezic, A., Petitjean, P., Thibault, J. N., \& Jeanneau, L. (2013). Hydrologically driven seasonal changes in the sources and production mechanisms of dissolved organic carbon in a small lowland catchment. Water Resources Research, 49, 5792-5803. https://doi.org/10.1002/wrcr.20466

Lloyd, C., Freer, J., Collins, A., Johnes, P., \& Jones, J. (2014). Methods for detecting change in hydrochemical time series in response to targeted pollutant mitigation in river catchments. Journal of Hydrology, 514, 297-312.

Loecke, T. D., Burgin, A. J., Riveros-Iregui, D. A., Ward, A. S., Thomas, S. A., Davis, C. A., \& Clair, M. A. S. (2017). Weather whiplash in agricultural regions drives deterioration of water quality. Biogeochemistry, 133(1), 7-15.

Marcé, R., Obrador, B., Gómez-Gener, L., Catalán, N., Koschorreck, M., Arce, M. I., et al. (2018). Emissions from dry inland waters are a blind spot in the global carbon cycle. Earth-Science Reviews, 188, 240-248.

Marshall, E., \& Randhir, T. (2008). Effect of climate change on watershed system: A regional analysis. Climatic Change, 89(3-4), 263-280.

Martin, C., Aquilina, L., Gascuel-Odoux, C., Molenat, J., Faucheux, M., \& Ruiz, L. (2004). Seasonal and interannual variations of nitrate and chloride in stream waters related to spatial and temporal patterns of groundwater concentrations in agricultural catchments. Hydrological Processes, 18(7), 1237-1254.

Marzadri, A., Dee, M. M., Tonina, D., Bellin, A., \& Tank, J. L. (2017). Role of surface and subsurface processes in scaling $\mathrm{N}_{2} \mathrm{O}$ emissions along riverine networks. Proceedings of the National Academy of Sciences, 114(17), 4330-4335.

Mellander, P. E., Jordan, P., Bechmann, M., Fovet, O., Shore, M. M., McDonald, N. T., \& Gascuel-Odoux, C. (2018). Integrated climate-chemical indicators of diffuse pollution from land to water. Scientific Reports, 8(1), 944.

Michalak, A. M. (2016). Study role of climate change in extreme threats to water quality. Nature News, 535(7612), 349-350.

Miguez-Macho, G., \& Fan, Y. (2012). The role of groundwater in the Amazon water cycle: 1. Influence on seasonal streamflow, flooding and wetlands. Journal of Geophysical Research, 117, D15113. https://doi.org/10.1029/2012JD017539

Minaudo, C., Meybeck, M., Moatar, F., Gassama, N., \& Curie, F. (2015). Eutrophication mitigation in rivers: 30 years of trends in spatial and seasonal patterns of biogeochemistry of the Loire River (1980-2012). Biogeosciences, 12(8), 2549-2563.

Molenat, J., Gascuel-Odoux, C., Davy, P., Durand, P., \& Gruau, G. (2002). Nitrate export from an agricultural basin: Control mechanisms and nitrate residence times. International Association of Hydrological Sciences, Publication, 273, 273-278.

Monteith, D. T., Evans, C., \& Reynolds, B. (2000). Are temporal variations in the nitrate content of UK upland freshwaters linked to the North Atlantic Oscillation? Hydrological Processes, 14(10), 1745-1749.

Monteith, D. T., Stoddard, J. L., Evans, C. D., de Wit, H. A., Forsius, M., Høgåsen, T., et al. (2007). Dissolved organic carbon trends resulting from changes in atmospheric deposition chemistry. Nature, 450(7169), 537-540. https://doi.org/10.1038/nature06316

Morel, B. (2009). Transport de carbone organique dissous dans un bassin versant agricole à nappe superficielle, Agrocampus - Ecole nationale supérieure d'agronomie de Rennes.

Morel, B., Durand, P., Jaffrezic, A., Gruau, G., \& Molenat, J. (2009). Sources of dissolved organic carbon during stormflow in a headwater agricultural catchment. Hydrological Processes, 23(20), 2888-2901.

Mulholland, P. J., \& Hill, W. R. (1997). Seasonal patterns in streamwater nutrient and dissolved organic carbon concentrations: Separating catchment flow path and in-stream effects. Water Resources Research, 33(6), 1297-1306.

Murphy, J., \& Riley, J. P. (1962). A modified single solution method for the determination of phosphate in natural waters. Analytica Chimica Acta, 27, 31-36.

Musolff, A., Schmidt, C., Selle, B., \& Fleckenstein, J. H. (2015). Catchment controls on solute export. Advances in Water Resources, 86, 133-146.

Newcomer, M. E., Hubbard, S. S., Fleckenstein, J. H., Maier, U., Schmidt, C., Thullner, M., et al. (2018). Influence of hydrological perturbations and riverbed sediment characteristics on hyporheic zone respiration of $\mathrm{CO}_{2}$ and $\mathrm{N}_{2}$. Journal of Geophysical Research: Biogeosciences, 123, 902-922. https://doi.org/10.1002/2017JG004090

Nickus, U., Bishop, K., Erlandsson, M., Evans, C. D., Forsius, M., Laudon, H., et al. (2010). Direct impacts of climate change on freshwater ecosystems. In Climate change impacts on freshwater ecosystems (pp. 38-64). Oxford, UK: Blackwell Publishing.

Ockenden, M. C., Hollaway, M. J., Beven, K. J., Collins, A., Evans, R., Falloon, P., et al. (2017). Major agricultural changes required to mitigate phosphorus losses under climate change. Nature Communications, 8(1), 161.

Oeurng, C., Sauvage, S., \& Sánchez-Pérez, J.-M. (2010). Temporal variability of nitrate transport through hydrological response during flood events within a large agricultural catchment in south-west France. Science Total of Environment, 409(1), 140-149.

Oni, S. K., Futter, M. N., Bishop, K., Kohler, S. J., Ottosson-Lofvenius, M., \& Laudon, H. (2013). Long-term patterns in dissolved organic carbon, major elements and trace metals in boreal headwater catchments: Trends, mechanisms and heterogeneity. Biogeosciences, 10(4), 2315-2330.

Osborn, H., \& Lane, L. (1969). Precipitation-runoff relations for very small semiarid rangeland watersheds. Water Resources Research, 5(2), 419-425.

Outram, F. N., Lloyd, C., Jonczyk, J., Benskin, C. M., Grant, F., Perks, M., et al. (2014). High-frequency monitoring of nitrogen and phosphorus response in three rural catchments to the end of the 2011-2012 drought in England. Hydrology and Earth System Sciences, 18(9), 3429-3448

Penman, H. L. (1956). Estimating evaporation. Eos, Transactions American Geophysical Union, 37(1), 43-50.

Petitjean, P., Henin, O., \& Gruau, G. (2004). Dosage du carbone organique dissous dans les eaux douces naturelles. Intérêt, Principe, Mise en Oeuvre et Précautions Opératoires. 
Ruiz, L., Abiven, S., Martin, C., Durand, P., Beaujouan, V., \& Molenat, J. (2002). Effect on nitrate concentration in stream water of agricultural practices in small catchments in Brittany: II. Temporal variations and mixing processes. Hydrology and Earth System Sciences, 6(3), 507-513

Salmon-Monviola, J., Moreau, P., Benhamou, C., Durand, P., Merot, P., Oehler, F., \& Gascuel-Odoux, C. (2013). Effect of climate change and increased atmospheric $\mathrm{CO}_{2}$ on hydrological and nitrogen cycling in an intensive agricultural headwater catchment in western France. Climatic Change, 120(1-2), 433-447.

Singh, N. K., Reyes, W. M., Bernhardt, E. S., Bhattacharya, R., Meyer, J. L., Knoepp, J. D., \& Emanuel, R. E. (2016). Hydro-climatological influences on long-term dissolved organic carbon in a mountain stream of the southeastern United States. Journal of Environmental Quality, 45(4), 1286-1295.

Srinivas, R., Singh, A. P., Dhadse, K., \& Garg, C. (2020). An evidence based integrated watershed modelling system to assess the impact of non-point source pollution in the riverine ecosystem. Journal of Cleaner Production, 246, 17.

Stuart, M., Gooddy, D., Bloomfield, J., \& Williams, A. (2011). A review of the impact of climate change on future nitrate concentrations in groundwater of the UK. Science Total of Environment, 409(15), 2859-2873.

Taylor, P. G., \& Townsend, A. R. (2010). Stoichiometric control of organic carbon-nitrate relationships from soils to the sea. Nature, 464(7292), 1178-1181.

Thomas, Z., Abbott, B., Troccaz, O., Baudry, J., \& Pinay, G. (2016). Proximate and ultimate controls on carbon and nutrient dynamics of small agricultural catchments. Biogeosciences, 13(6), 1863-1875.

UMR SAS (2010). Observatoire de Recherche en Environnement sur les Agro-Hydrosystèmes (ORE AgrHyS), INRAE. https://doi.org/ $10.15454 / 1.5499682911557678 \mathrm{e} 12$

Van Meter, K. J., Chowdhury, S., Byrnes, D. K., \& Basu, N. B. (2019). Biogeochemical asynchrony: Ecosystem drivers of seasonal concentration regimes across the Great Lakes Basin. Limnology and Oceanography, 65, 848-862.

Vautard, R., \& Yiou, P. (2009). Control of recent European surface climate change by atmospheric flow. Geophysical Research Letters, 36, L22702. https://doi.org/10.1029/2009GL040480

Viaud, V., Santillàn-Carvantes, P., Akkal-Corfini, N., Le Guillou, C., Prévost-Bouré, N. C., Ranjard, L., \& Menasseri-Aubry, S. (2018). Landscape-scale analysis of cropping system effects on soil quality in a context of crop-livestock farming. Agriculture, Ecosystems \& Environment, 265, 166-177.

Wang, L. L., Flanagan, D. C., Wang, Z. G., \& Cherkauer, K. A. (2018). Climate change impacts on nutrient losses of two watersheds in the Great Lakes region. Water, 10(4), 442

Weigand, S., Bol, R., Reichert, B., Graf, A., Wiekenkamp, I., Stockinger, M., et al. (2017). Spatiotemporal analysis of dissolved organic carbon and nitrate in waters of a forested catchment using wavelet analysis. Vadose Zone Journal, 16(3), vzj2016.09.0077. https://doi.org/ 10.2136/vzj2016.09.0077

Whitehead, P. G., Wilby, R. L., Battarbee, R. W., Kernan, M., \& Wade, A. J. (2009). A review of the potential impacts of climate change on surface water quality. Hydrological Sciences Journal, 54(1), 101-123.

Worrall, F., \& Burt, T. (2007). Trends in DOC concentration in Great Britain. Journal of Hydrology, 346(3-4), 81-92.

Ye, F., \& Kameyama, S. (2020). Long-term spatiotemporal changes of 15 water-quality parameters in Japan: An exploratory analysis of countrywide data during 1982-2016. Chemosphere, 242, 125245 